Because of the Geological Society of London regulations, this is the authors original BGS-edited submitted manuscript copy of the paper published in 2020. It contains minor differences from the published version which includes some corrections, updates and additions. If the reader finds this draft useful and wishes to quote it, they should check the published version for corrections. The paper is published as:

Cooper, A.H. 2020. Geohazards caused by gypsum and anhydrite in the UK: including dissolution, subsidence and heave. in Giles, D. P. \& Griffiths, J. S. (eds) 2020. Geological Hazards in the UK: Their Occurrence, Monitoring and Mitigation Engineering Group Working Party Report. Geological Society, London, Engineering Geology Special Publications, 29, 403-423, https://doi.org/10.1144/EGSP29.16

\title{
Geohazards caused by gypsum and anhydrite in the UK: including dissolution, subsidence, sinkholes and heave
}

Anthony H. Cooper

Honorary research associate, British Geological Survey, Keyworth, Nottingham, NG12 5GG. ahc@bgs.ac.uk

\section{Abstract}

Gypsum and anhydrite are both soluble minerals forming rocks that can dissolve at surface and underground resulting in sulphate karst causing geological hazards, especially subsidence and sinkholes at the surface. The dissolution rates of these minerals are rapid and cavities/caves can enlarge and collapse on a human time scale. In addition, the hydration and recrystallisation of anhydrite to gypsum can cause considerable expansion and pressures capable of causing uplift and heave. Sulphaterich water associated with the deposits can react with concrete and be problematic for construction. This paper reviews the occurrence of gypsum and anhydrite in the near surface of the UK and looks at methods for mitigating, avoiding and planning for the problems associated with these rocks.

\section{Introduction}

Gypsum, hydrated Calcium Sulphate $\left(\mathrm{CaSO}_{4} \cdot 2 \mathrm{H}_{2} \mathrm{O}\right)$, is attractive as satin spar, beautiful as carved alabaster and practical as plasterboard (wallboard) and plaster. However, gypsum is highly soluble and a cause of geological hazards capable of causing severe subsidence to houses, roads and bridges. Gypsum dissolves rapidly and where this occurs underground it results in caves that evolve and quickly enlarge commonly leading to subsidence and sometimes to catastrophic collapse. Gypsum is mainly a secondary mineral present in the UK mainly as fibrous gypsum (satin spar) and alabastrine gypsum (alabaster) which may include large crystals and aggregates of crystals; it occurs near surface passing into anhydrite, the dehydrated form $\left(\mathrm{CaSO}_{4}\right)$ at depths below about 40 to $120 \mathrm{~m}$ or so depending on the local geology and water circulation. The hydration of anhydrite to gypsum in the subsurface causes expansion and heave that are problematic to engineering and hydrogeological installations such as ground source heat pumps. Furthermore, gypsum especially in engineering fills can react with cement causing 
heave. Gypsum and anhydrite are present in the Triassic strata of the Midlands and south-west of the UK and in the Permian strata of the north-east and north-west of England. In all these areas various geological hazards are associated with these rocks the most visible being subsidence and sinkholes. Gypsum and anhydrite also occur to a small extent in the Jurassic of southern England, but no specific problems have been reported related to these deposits.

\section{The gypsum-anhydrite transition, expansion and heave}

Gypsum is hydrated calcium sulphate $\mathrm{CaSO}_{4} \cdot 2 \mathrm{H}_{2} \mathrm{O}$, the dehydrated form being anhydrite $\mathrm{CaSO}_{4}$. Gypsum is the most common form found in modern evaporitic sedimentary environments (such as sabkahs in the Gulf (Kendall and Alsharhan 2011)), but upon burial it dehydrates to anhydrite. This dehydration generally occurs at depths of between 450 metres (Klimchouk and Andrejchuk 1996) and 1200 metres (Mossop and Shearman 1973) reaching a theoretical maximum of around 4000 metres (dependent on geothermal gradient and the nature of groundwater fluids and overlying strata (Jowett et al. 1995)). Anhydrite hydrates to gypsum with a significant increase in volume of about 61- 63\% (Boidin et al. 2009; Mossop and Shearman 1973). Upon exhumation and uplift the anhydrite becomes metastable and if sufficient water is available it can hydrate back to gypsum, this process can be enhanced by dissolved salts in the groundwater. This re-hydration tends to happen in the UK at depths of between about 150 and 80 metres. However, it can be much deeper in proximity to faults and restricted to shallower depths if the adjacent strata are aquitards. The hydration not only changes in situ anhydrite to gypsum (mainly forming alabastrine gypsum), but it also produces fluids containing calcium sulphate that is deposited out as fibrous gypsum. The expansion processes produces high pressures of between 1 and $5 \mathrm{MPa}$ (Einstein 1996) which can fracture the rock, cause folding (James et al. 1981) and uplift of the sequence. The pressures generated by the hydration, recrystallisation and gypsum growth can be very high, sufficient to cause uplift of more than $80 \mathrm{~m}$ of overlying strata. In Staufen (Germany), the misjudgement of drilling boreholes through anhydrite and the installation of ground source heat pumps has caused heave that has damaged more than 131 buildings (Goldscheider and Bechtel 2011). The web report by the Staufen administrators (Staufen City Administration 2012) noted the presence of $75 \mathrm{~m}$ of anhydrite in boreholes $140 \mathrm{~m}$ deep and overall uplift of $1 \mathrm{~cm}$ a month $(20 \mathrm{~cm}$ when reported); the damage caused was put at least $€ 40$ Million. Considerable heave in tunnels through anhydrite has also been reported (Boidin et al. 2009; Einstein 1996) as have the problems of dissolution (Gysel 2002). Despite these observations of expansion, a recent investigation of the abandoned, flooded Warren Anhydrite Mine at Hartlepool (Borehole NZ53SW/147: cores donated to the British Geological Survey in 2001) showed no significant expansion of the country rock and only a thin alteration to gypsum of the surface. This lack of alteration of anhydrite was also noted in anhydrite from French mines, where the lack of porosity was given as the cause for the slow reaction of the anhydrite (Boidin et al. 2009). It is known that small amounts of dissolved elements can have a catalytic effect on the hydration processes (Klimchouk 2000), but the precise details are largely unknown. It is also worth noting that gypsum is also associated with heave where pyritic materials weather and react with 
carbonate in ground and surface water producing gypsum (Czerewko et al. 2011; Hawkins and Pinches 1987). This occurs in both natural and anthropogenic deposits.

A further related consideration is the reaction of concrete or cement stabilisation binder with sulphate-rich groundwater associated with gypsum, anhydrite and pyritic materials. The reactions with the cement can cause the expansive formation of ettringite and thaumasite and detrimental damage to cement and concrete structures or heave of fill and stabilised soils (Crammond 2003; Czerewko et al. 2011; Forster et al. 1995; Longworth 2004). These constructional problems should be borne in mind when undertaking construction in gypsum karst areas or where sulphate minerals occur.

\section{The gypsum dissolution problem}

Gypsum dissolves readily in flowing water, which next to rivers can be at a rate about 100 times faster than that seen for limestone dissolution. James et al. (1981) observed a $3 \mathrm{~m}$ cube of gypsum being dissolved completely by the River Ure near Ripon in about 18 months; the associated gypsum face was then undercut by $6 \mathrm{~m}$ in the subsequent 10 years (Figure 1). This dissolution rate is for turbulent unsaturated water at the surface. Underground dissolved sulphate in the water slows the dissolution, but it is still very rapid and caves in gypsum can readily form and expand (Klimchouk 1996; Klimchouk and Andrejchouk 2005; Klimchouk and Andrejchuk 1996; Klimchouk et al. 1996a). Such caves occur in the Vale of Eden, Cumbria and are inferred beneath Ripon, North Yorkshire (Ryder and Cooper 1993; Waltham and Cooper 1998). Some of the longest and most complex cave (maze cave) systems in the world are developed in the gypsum karst of the Ukraine (Klimchouk 1992; Klimchouk et al. 1996b) and it is thought that similar water-filled (phreatic) caves exist beneath Ripon and other parts of eastern England underlain by similar strata. Under suitable groundwater flow conditions caves in gypsum can enlarge at a rapid rate resulting in large chambers. Collapse of these chambers produces breccia pipes that propagate through the overlying strata to break through at the surface and form subsidence hollows. Subsidence problems at Ripon are due to this phenomenon (Cooper 1986, 1989, 1998, 2002, 2007; Cooper and Calow 1998) 

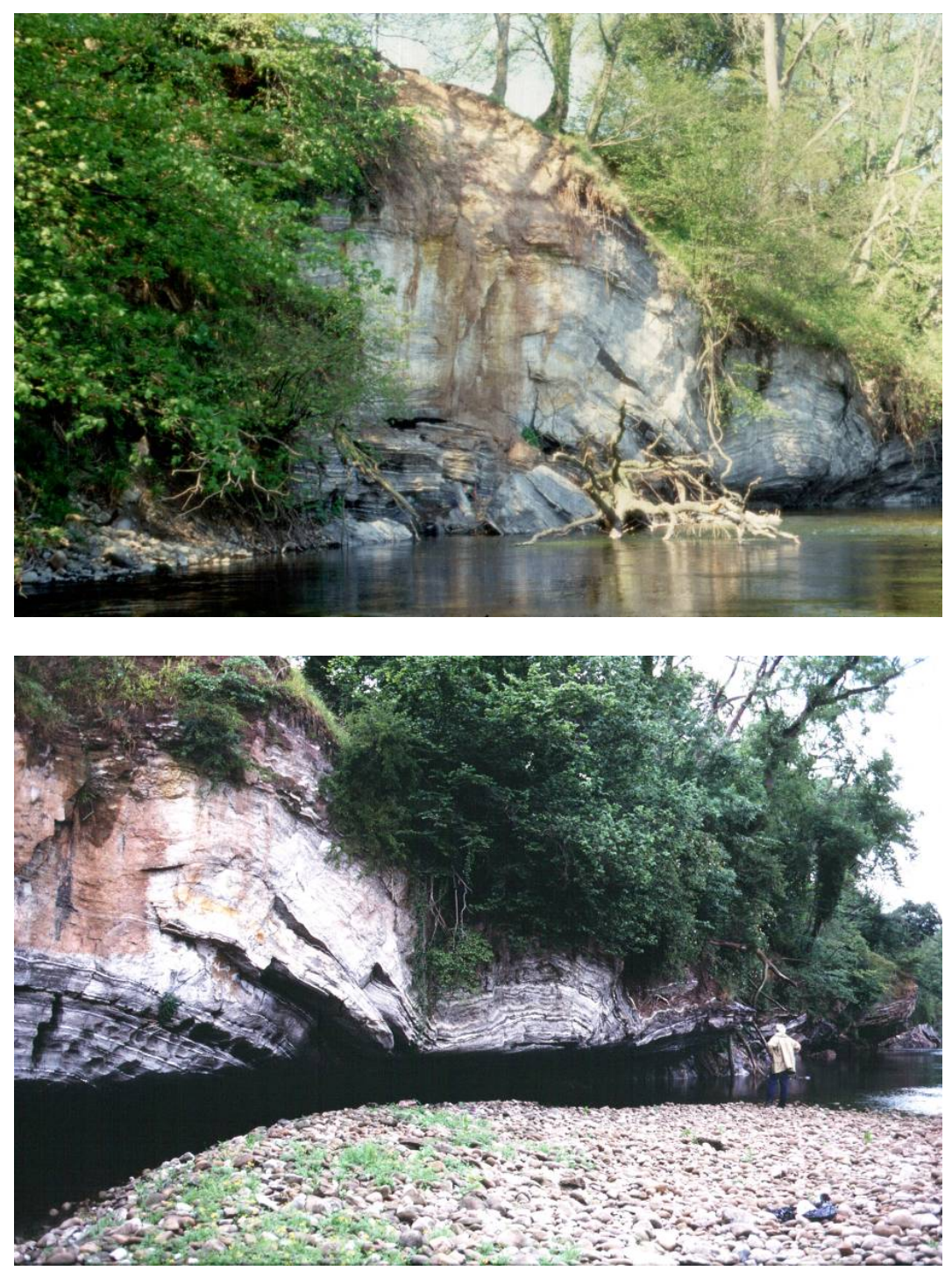

Figure 1. Ripon Parks gypsum in 1979 (top) when it had just collapsed and 1990 (bottom) showing the undercutting of the cliff by about 6 metres due to dissolution from the River Ure. Soon after this lower picture was taken the cliff collapsed again. (Photos A H Cooper $\mathbb{C}$ NERC/BGS).

\section{Geology of the gypsiferous rocks}

\section{Triassic}

Triassic Mercia Mudstone Group strata in the Midlands of the UK (Table 1 and Figure 2) have several units of gypsum within them, notably the Tutbury Gypsum and the Newark Gypsum. These occur in what is now called the Branscombe Mudstone Formation (formerly the Cropwell Bishop Formation). The Tutbury Gypsum is a massive unit generally 2-3 m thick with diapiric monoliths up to $9 \mathrm{~m}$ thick (Noel Worley pers. comm. Yorkshire Geological Society field excursion $24^{\text {th }}$ July 2011). This gypsum is mined in Staffordshire at Fauld Mine and was formerly mined and quarried in the Chellaston area near Derby (Smith 1918; Wynne 1906; Young 1990). 
In this area and eastwards towards Nottingham the rock is partly dissolved towards outcrop and some cavities are present (Cooper 1996; Cooper and Saunders 2002; Jago 2013). The Newark gypsum comprises a sequence of thin to thick beds spaced over a thickness of about 25 metres of sequence containing about $25 \%$ gypsum beds. The Newark gypsum was formerly mined at Orston (23 km east of Nottingham) and is now opencast mined near Newark about $25 \mathrm{~km}$ north-east of Nottingham (Firman 1964, 1984; Worley and Reeves 2007).

\begin{tabular}{|c|c|c|c|c|c|}
\hline \multirow{2}{*}{$\begin{array}{c}\text { Chrono- } \\
\text { stratigraphy }\end{array}$} & \multicolumn{3}{|c|}{ Lithostratigraphy } & \multirow{2}{*}{ Lithology } & \multirow{2}{*}{$\begin{array}{c}\text { Approx } \\
\text { thickness }\end{array}$} \\
\hline & \multirow{7}{*}{ 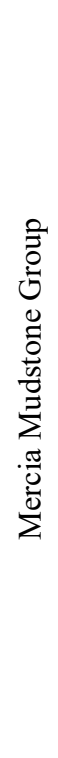 } & Formation & Member & & \\
\hline \multirow{6}{*}{ Triassic } & & Blue Anchor Fm & & $\begin{array}{c}\text { Dolomitic } \\
\text { mudstone and } \\
\text { siltstone }\end{array}$ & $8 \mathrm{~m}$ \\
\hline & & \multirow{4}{*}{$\begin{array}{c}\text { Branscombe } \\
\text { Mudstone Fm } \\
\text { (formerly } \\
\text { Cropwell Bishop } \\
\text { Fm) }\end{array}$} & $\begin{array}{l}\text { Newark } \\
\text { Gypsum }\end{array}$ & $\begin{array}{l}\text { Interbedded red- } \\
\text { brown mudstone } \\
\text { and mainly white } \\
\text { thin to medium } \\
\text { bedded alabastrine } \\
\text { gypsum }\end{array}$ & Up to $25 \mathrm{~m}$ \\
\hline & & & & $\begin{array}{l}\text { Red-brown } \\
\text { mudstone }\end{array}$ & $10 \mathrm{~m}$ \\
\hline & & & $\begin{array}{l}\text { Tutbury } \\
\text { Gypsum }\end{array}$ & $\begin{array}{l}\text { Massive to large } \\
\text { nodular white and } \\
\text { mottled mainly } \\
\text { alabastrine gypsum }\end{array}$ & $1-9 \mathrm{~m}$ \\
\hline & & & & $\begin{array}{l}\text { Red-brown } \\
\text { mudstone }\end{array}$ & $16 \mathrm{~m}$ \\
\hline & & $\begin{array}{c}\text { Arden Sandstone } \\
\text { Fm }\end{array}$ & & $\begin{array}{l}\text { Dominantly } \\
\text { sandstone }\end{array}$ & Up to $17 \mathrm{~m}$ \\
\hline
\end{tabular}

Table 1. The gypsiferous Triassic sequence forming part of the Mercia Mudstone Group in the English Midlands 


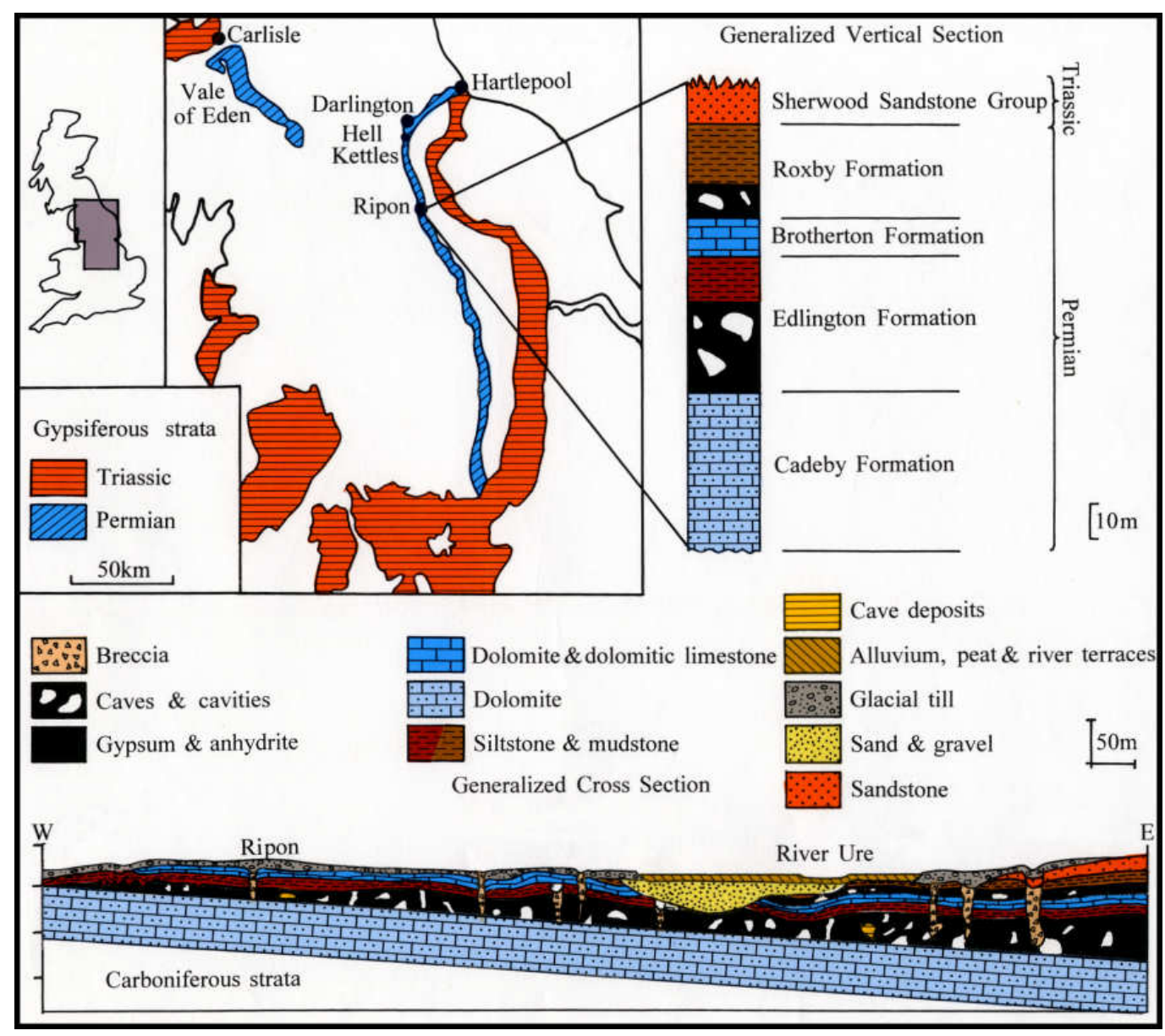

Figure 2. Regional geology of the Permian and Triassic gypsiferous sequences with a crosssection from west to east through the Ripon area showing the easterly dipping dolomite and gypsum sequence cut into by the glacial valley of the River Ure.

\section{Permian}

Most of the Permian sequence of eastern England belongs to the Zechstein Group which includes dolomites, mudstones and gypsum at outcrop with diverse evaporites deeper in the basin to the east. The general stratigraphy at outcrop is shown below in Table 2. Both the Edlington Formation and Roxby Formation are notable for containing thick gypsum that reaches its maximum around Ripon, thins both to the north and south, but thickens again around Darlington. Eastwards towards Billingham and Hartlepool the sulphate occurs mainly as anhydrite having not been converted back to gypsum. To the south the gypsum gets thinner so that it has largely gone at Doncaster. The distribution of the gypsum extends from outcrop, where it is partially dissolved, to a depth of around 90-120 metres where it passes into anhydrite. This gypsum zone defines a belt about 2-3 $\mathrm{km}$ wide where gypsum can dissolve in the subsurface causing subsidence. 


\begin{tabular}{|c|c|c|c|}
\hline $\begin{array}{c}\text { Chrono- } \\
\text { stratigraphy }\end{array}$ & Lithostratigraphy & Lithology & $\begin{array}{c}\text { Approx } \\
\text { thickness at } \\
\text { outcrop } \\
\end{array}$ \\
\hline Triassic & $\begin{array}{l}\text { Sherwood Sandstone Group } \\
\text { formerly Bunter Sandstone }\end{array}$ & $\begin{array}{l}\text { Red-brown sandstone, pebbly in } \\
\text { the south }\end{array}$ & $50-350 \mathrm{~m}$ \\
\hline \multirow{5}{*}{ Permian } & $\begin{array}{l}\text { Roxby Formation } \\
\text { (Zechstein Group) } \\
\text { formerly Upper Marl }\end{array}$ & $\begin{array}{c}\text { Up to } 10 \mathrm{~m} \text { of gypsum/anhydrite } \\
\text { overlain by } 0 \text { - } 20 \mathrm{~m} \text { of red-brown } \\
\text { mudstone with up to } 10 \mathrm{~m} \text { of } \\
\text { gypsum }\end{array}$ & $0-30 \mathrm{~m}$ \\
\hline & $\begin{array}{c}\text { Brotherton Formation } \\
\text { (Zechstein Group) } \\
\text { formerly Upper Magnesian } \\
\text { Limestone } \\
\end{array}$ & $\begin{array}{l}\text { Mainly thin-bedded dolomite and } \\
\text { dolomitic limestone }\end{array}$ & $0-30 \mathrm{~m}$ \\
\hline & $\begin{array}{r}\text { Edlington Formation } \\
\text { (Zechstein Group) } \\
\text { formerly Middle Marl }\end{array}$ & $\begin{array}{l}\text { Up to } 35 \mathrm{~m} \text { of gypsum/anhydrite } \\
\text { overlain by } 0-20 \mathrm{~m} \text { of red-brown } \\
\text { mudstone with up to } 40 \mathrm{~m} \text { of } \\
\text { gypsum }\end{array}$ & $0-55 \mathrm{~m}$ \\
\hline & $\begin{array}{c}\text { Cadeby Formation } \\
\text { (Zechstein Group) } \\
\text { formerly Lower Magnesian } \\
\text { Limestone } \\
\end{array}$ & $\begin{array}{c}\text { Massive and bedded dolomite with } \\
\text { reefs and algal stromatolites } \\
\text { overlain by cross-bedded oolitic } \\
\text { dolomite. }\end{array}$ & $0-50 \mathrm{~m}$ \\
\hline & $\begin{array}{c}\text { Yellow Sands Formation } \\
\text { and basal breccia } \\
\text { (Rotliegendes Group) }\end{array}$ & $\begin{array}{l}\text { Lenticular areas of locally derived } \\
\text { breccia overlain by aeolian yellow } \\
\text { fine to medium grained sandstone. }\end{array}$ & $0-10 \mathrm{~m}$ \\
\hline Carboniferous & & $\begin{array}{l}\text { Mixed sequence of mudstone, } \\
\text { siltstone, coal and sandstone. }\end{array}$ & $\begin{array}{l}\text { Up to } \\
3000 \mathrm{~m}\end{array}$ \\
\hline
\end{tabular}

Table 2. Generalised Permian sequence of eastern England

In the north-west of England gypsum/anhydrite is extensively present in the Vale of Eden. Here there is a localised sequence of four gypsum beds (A, B, C and D in ascending order - Table 3) interbedded with mudstone and overlying the aquifer of the Permian Penrith Sandstone (Arthurton and Wadge 1981; Burgess and Holliday 1979; Holliday 1993; Meyer 1965; Sherlock and Hollingworth 1938). The upper three beds are persistent, but the thick A-Bed is localised to the middle part of the Vale of Eden. Throughout the area the gypsum and anhydrite have been extensively mined, but very little information is in the public domain (Rogers 1994; Tyler 2000). On the coast and at depth in the Solway basin a different sequence is present with anhydrite of the St Bees Evaporite Formation (Sandwith and Fleshwick cycles) present in the St Bees area; here the Sandwith anhydrite was formerly mined, but no karstic features have been noted (Akhurst et al. 1997; Tyler 2000)

\begin{tabular}{|l|l|l|}
\hline $\begin{array}{l}\text { Gypsum } \\
\text { units }\end{array}$ & Characteristics & Thickness in Vale of Eden \\
\hline D-Bed & $\begin{array}{l}\text { Massive and nodular gypsum/anhydrite with fibrous } \\
\text { gypsum; underlain by up to 8 } \mathrm{m} \text { of the Belah Dolomite }\end{array}$ & Up to 3.7 $\mathrm{m}$ widespread \\
\hline C-Bed & $\begin{array}{l}\text { Interbedded nodular and bedded gypsum/ anhydrite with } \\
\text { fibrous gypsum and mudstone }\end{array}$ & Up to $3.8 \mathrm{~m}$ widespread \\
\hline B-Bed & Massive fine-grained gypsum and anhydrite & Up to $6.5 \mathrm{~m}$ widespread \\
\hline A-Bed & $\begin{array}{l}\text { Interbedded gypsum/anhydrite and fibrous gypsum with } \\
\text { abundant mudstone; closely underlain by the Penrith } \\
\text { Sandstone aquifer }\end{array}$ & $\begin{array}{l}\text { Up to } 42.4 \mathrm{~m} \text { limited to central } \\
\text { area failing to north and south. }\end{array}$ \\
\hline
\end{tabular}

Table 3. The Permian evaporite units in the Vale of Eden, Cumbria 


\section{Subsidence caused by gypsum dissolution}

\section{Subsidence geohazards at Ripon}

The Permian sequence at Ripon contains approximately 35-40 m of gypsum in the Edlington Formation and $10 \mathrm{~m}$ of gypsum higher up in the Roxby Formation (Powell et al. 1992; Cooper and Burgess 1993; Cooper 1998). These two gypsum sequences rest on two limestone aquifers, the Cadeby Formation and the Brotherton Formation respectively. The limestone dip slopes act as catchment areas and the water is fed down-dip into the gypsiferous sequences, before escaping into a major buried valley along the line of the Rive Ure (Figure 2 and (Cooper and Burgess 1993). Complex cave systems are developed in the gypsum and artesian sulphate-rich springs are locally present. Because of the thickness of gypsum present the caves are large and surface collapses up to $30 \mathrm{~m}$ across and $20 \mathrm{~m}$ deep have been recorded. The subsidence is not random, but occurs in a reticulate pattern related to the jointing in the underlying strata (Cooper 1986). Around Ripon a significant subsidence occurs approximately every few years (Cooper 1998); the times of the subsidence events show that some zones of subsidence are more active than others.

At Ripon the bedrock is cut through by a deep, largely buried, valley approximately following the course of the River Ure, and partially filled with up to $22 \mathrm{~m}$ of Devensian glacial and post-glacial deposits (Cooper and Burgess 1993; Powell et al. 1992). The buried valley intersects the carbonate and gypsum units creating a hydrological pathway from the bedrock to the river. Considerable groundwater flow occurs along this pathway and artesian water emanates from the Permian strata as springs which issue along the valley sides and up through the Ure valley gravels (Cooper, 1986, 1988; Cooper et al. 2013; Thompson et al. 1996). Artesian water, with a head above that of the river, has been encountered in some boreholes. Much of this water is nearly saturated with, or rich in dissolved calcium sulphate resulting from the dissolution of gypsum.

The greatest concentration of active subsidence hollows coincides with the areas marginal to the buried valley. Much of the sand and gravel partially filling the valley is cemented with calcareous tufa deposited from the groundwater which is also rich in dissolved carbonate (Cooper 1988). Subsidence is more extensive than it appears on the floodplain of the River Ure, because many of the subsidence features are infilled by overbank deposits (Cooper 1989, 1998). 


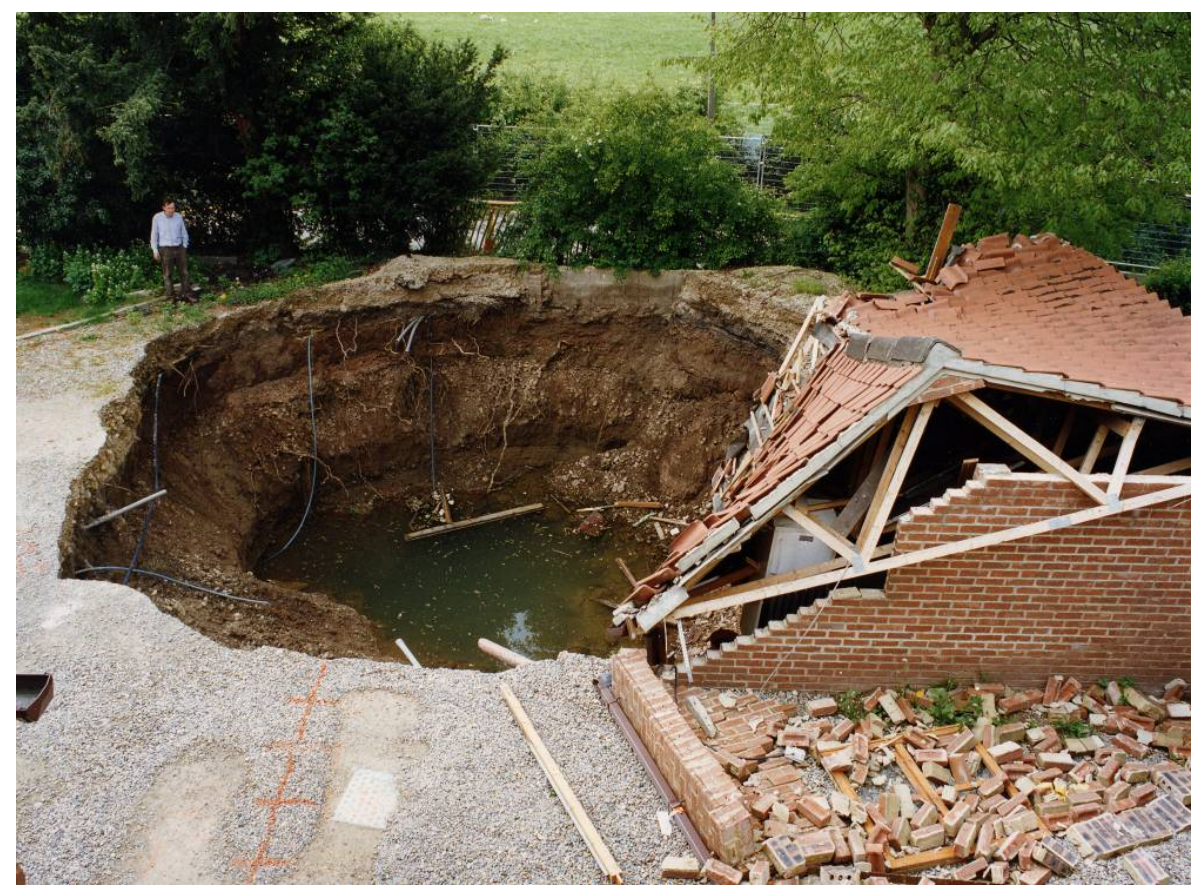

Figure 3. Sinkhole that formed in 1997 on Ure Bank, Ripon destroying 4 garages (category 7 damage) and damaging the adjacent house (Photo P Tod $\odot$ NERC/BGS).

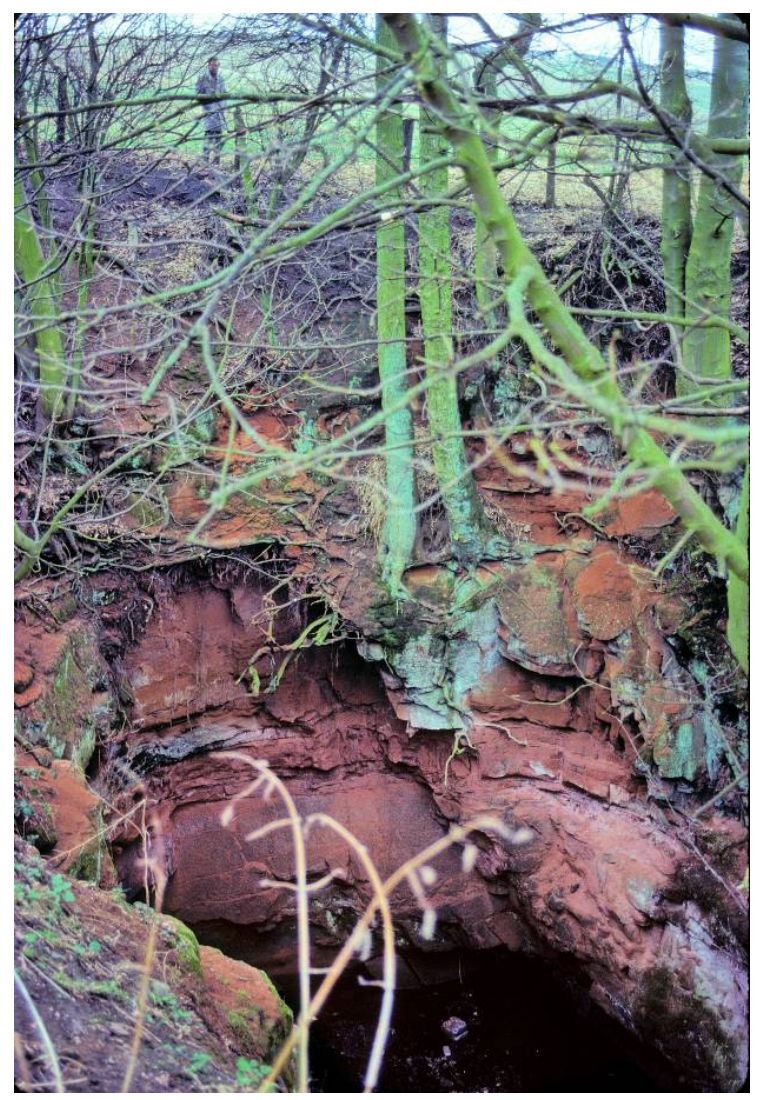

Figure 4. Sinkhole that formed in July 1834 near Ripon Railway Station. The hole is in red Sherwood Sandstone and was $20 \mathrm{~m}$ deep and $14 \mathrm{~m}$ across when it formed (Photo A H Cooper () NERC/BGS). 


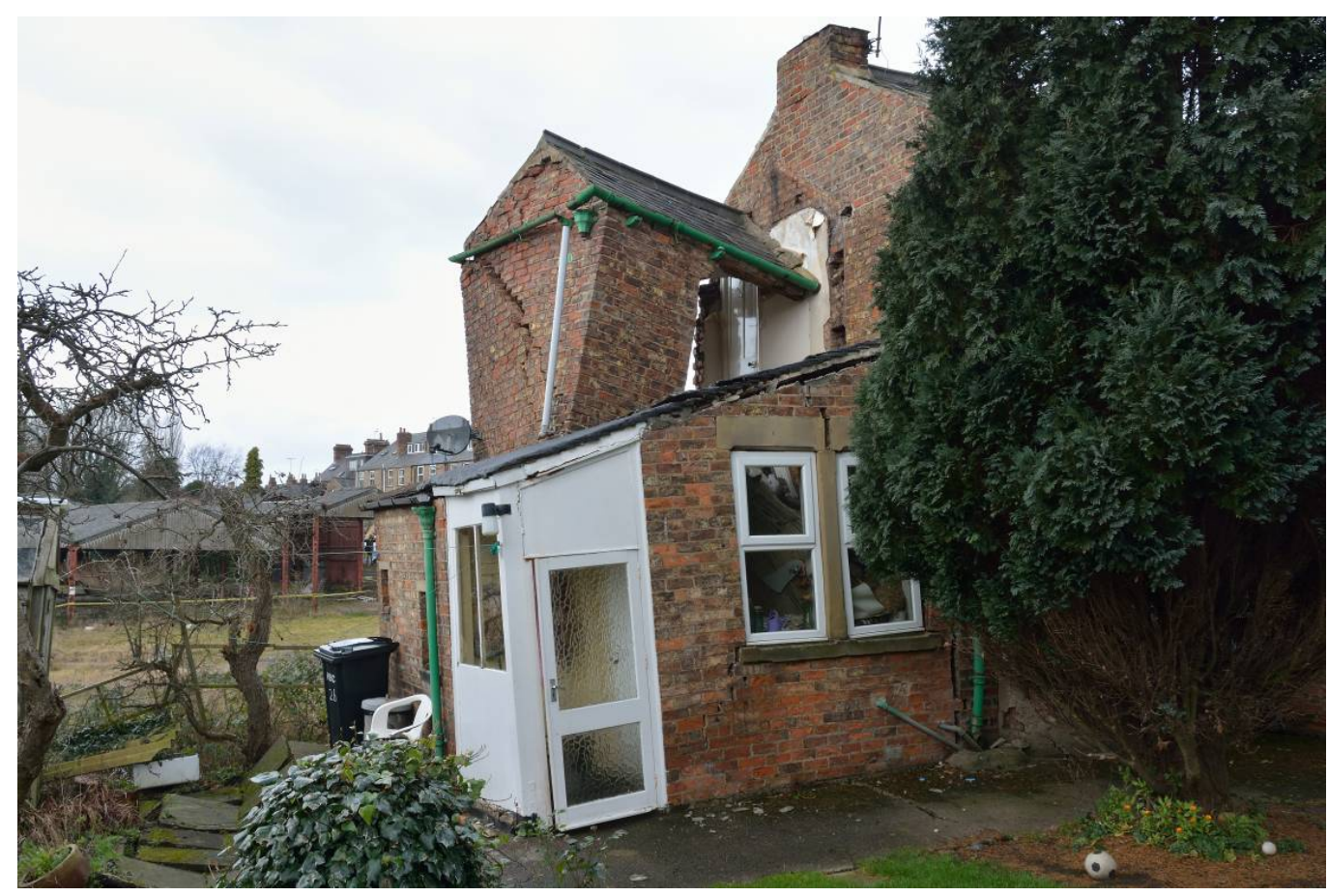

Figure 5. Severe building damage (category 7) that occurred on the night of February $17^{\text {th }} 2014$ at Magdalens Close, Ripon caused by a sinkhole, possibly triggered by heavy antecedent rainfall. (Photo A H Cooper (C) NERC/BGS).

The subsidence has been mapped from its surface expression as sinkholes or dolines and by looking at building damage (Figures 3,4 and 5). Several building damage surveys have been carried out; the technique used is based on an extended version of the subsidence damage recording scheme introduced by the National Coal Board (Cooper 2008a) and scores the damage from 1 which is very minor to 7 which is complete collapse. Information from a survey by is shown in Figure 6. Information about building damage, sinkholes, springs, stream sinks and caves for Ripon have being gathered by the British Geological Survey and stored in a Geographic Information System and associated databases (Cooper 2008b; Cooper et al. 2001; Cooper et al. 2011; Farrant and Cooper 2008). This database now has information for gypsum and salt karst features covering most of the country; it also contains information about limestone and chalk for about half of the country. 


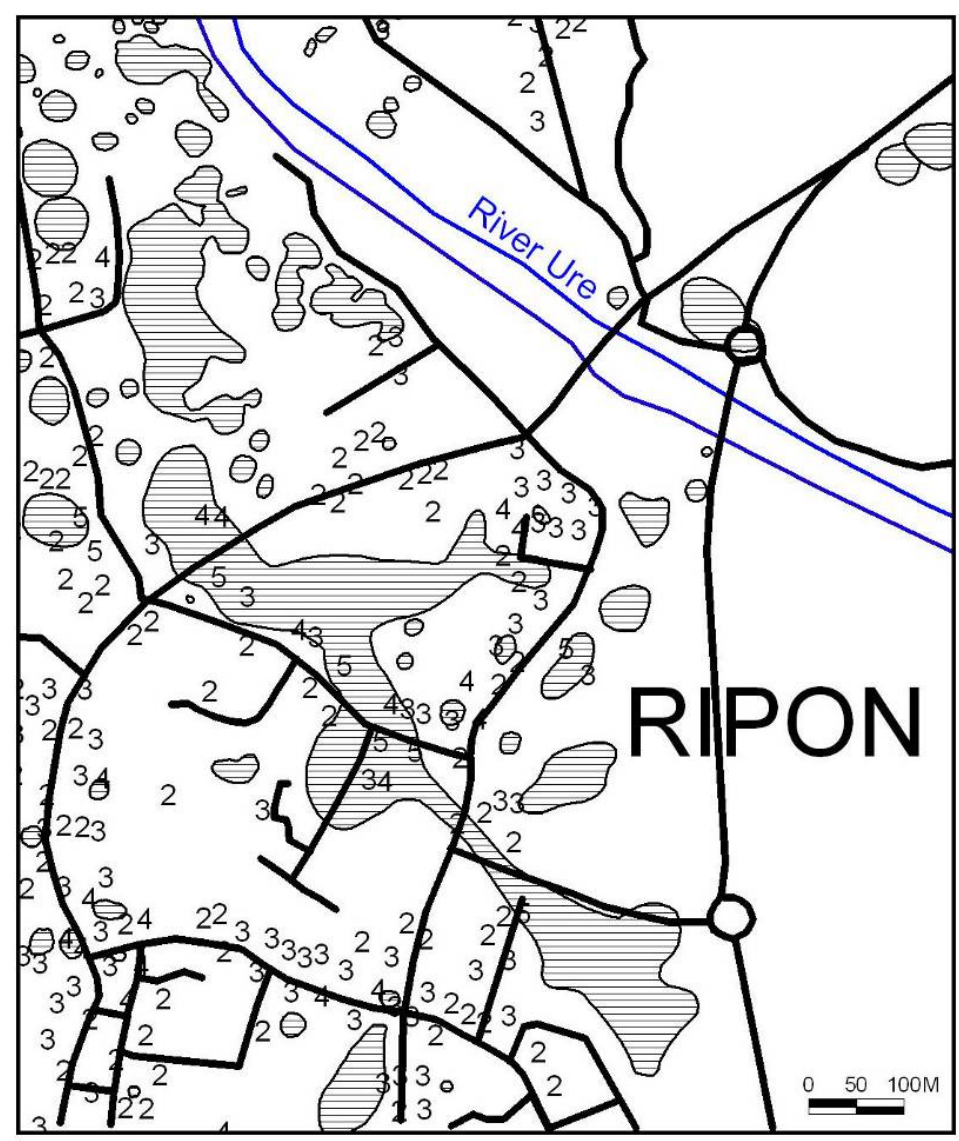

Figure 6. Building damage recording in Ripon by McNerney (2000) and included in the British Geological Survey karst GIS database; subsidence hollows shown with horizontal ornament in part of Ripon; from Cooper 2008a. See also Figure 10.

\section{Subsidence geohazards at Darlington}

The subsidence-prone belt extends from Ripon northwards to Darlington and Hartlepool (Figure 2), where the sequence is similar to that at Ripon, but the carbonate formations have different names. Around Darlington up to $40 \mathrm{~m}$ of gypsum is present in the Edlington Formation and up to $7 \mathrm{~m}$ in the Roxby Formation. Two types of subsidence occur in this northern area - catastrophic collapse similar to that at Ripon and more widespread settlement. The distinction between the two types is controlled by the hydrogeology and the thickness and lithology of the overlying glacial deposits (LamontBlack et al. 1999, 2002).

South of Darlington at Hells Kettles, catastrophic collapse occurred in 1179. Four subsidence hollows up to $35 \mathrm{~m}$ in diameter and $6 \mathrm{~m}$ deep were formerly present (Longstaffe 1854), but one of these is now filled in. These hollows are very similar to those at Ripon (Cooper 1986, 1998). Artesian water emanates from Hell Kettles and from sulphate-rich springs nearby at Croft (Cooper et al. 2013; Lamont-Black et al. 2005). Like Ripon, the sequence here dips gently eastwards and the outcrop of the carbonate formations is a groundwater recharge area. The ground water moves downdip to the low ground of the wide, partly-buried, valley of the River Tees. The subsidence appears to be associated with the margins of the buried valley, as at Ripon. 
The southern half of Darlington has suffered subsidence related to gypsum dissolution. Here most of the subsidence has been prolonged, less severe (generally less than $0.3 \mathrm{~m}$ ), and spread over subsidence depressions up to several hundred metres in diameter. Local boreholes have proved thick gypsiferous strata similar to those at Ripon, and cavities were encountered in one borehole. The bedrock surface forms a very broad valley filled with around $50 \mathrm{~m}$ of glacial and post-glacial deposits which include water-saturated sand and plastic laminated clays (Lamont-Black et al. 2002). As the gypsum dissolution proceeds, it appears that for much of the area the overlying water-saturated sand flows into the gypsum cavities. Support is removed over wide areas causing broad subsidence depressions at the surface. In addition to numerous broad subsidence features one small sinkhole has been recorded. It was $1.5 \mathrm{~m}$ diameter by $1 \mathrm{~m}$ deep and appeared near the river in the southern part of Skerne Park on $21^{\text {st }}$ February 2011 (NGR 428294, 513271); it was remediated with free-draining fill and fenced. The subsidence-prone belt continues to the north-east of Darlington, extending towards the coast at Hartlepool, where thick deposits of anhydrite underlie part of the town. Here they have been mined at several levels in Warren Mine. Boreholes here, to examine the mine and country rock, found very little gypsum, except at the contact with the overlying superficial deposits and no subsidence has been recorded in the town.

\section{Subsidence geohazards in the Vale of Eden}

Permian gypsum is present in the Vale of Eden where four gypsum units are present in the Eden Shales. The thickest unit is the A-Bed comprising interlayered gypsum and mudstone and the most uniform high quality and prominent unit the B-Bed gypsum. Both the A and B beds have been extensively quarried and mined, the C-Bed has also been worked in places (Arthurton and Wadge 1981; Hughes 2003; Mottahed and Szeki 1982).

Evidence of gypsum dissolution, in the B-Bed, was recorded in the Newbiggin gypsum opencast site where caves and a karstified gypsum surface were recorded by (Ryder and Cooper 1993). They also noted an open cavity migrating towards the surface through the overlying Eden Shales from a cavity in the gypsum below. Similar dissolution features were recorded in the A-Bed where it was formerly opencast at Kirkby Thore (Sherlock and Hollingworth 1938). Dissolution features have also been recorded in the mine workings in the lower part of the A-Bed with bee-hive shaped caves up to $9 \mathrm{~m}$ high and horizontal caves about $2 \mathrm{~m}$ high and up to 5 or 6 mine pillars long (c. $35 \mathrm{~m}$ ) proved (Dunham and Hollingworth 1947; Rogers 1994). These natural cavities are commonly water-filled and become more common in proximity to faulting their presence limiting the areas that could be mined (Rogers 1994). They are also more common in the lower part of the A-Bed sequence where the underlying Penrith Sandstone aquifer provides water that has dissolved the gypsum. The individual outcrops of gypsum in the Vale of Eden are narrow, but within them and the intervening mudstones subsidence has been recorded, both associated with the extensive mining and with areas that have not been mined; the presence of the rock is a concern for development in the areas where it is present at shallow to moderate depths. 


\section{Subsidence over Triassic gypsum}

Compared with the Permian sequence, dissolution of the Triassic gypsum generally has less catastrophic effects. This is largely due to the sequence being mainly of mudstone/siltstone and gypsum without the aquifers that are present in the Permian rocks. In Staffordshire, Derbyshire, Nottinghamshire and northern Leicestershire the gypsum is thick enough to be extensively mined and massive gypsum may reach $9 \mathrm{~m}$ thick (for example in diapiric monoliths in Fauld Mine). Evidence of dissolution of the gypsum is locally shown by the way the old mines exploited the rock and terminated their mining operations when they encountered the partly dissolved and collapsed areas (Cooper 1996; Cooper and Saunders 2002). Evidence of active dissolution is also shown by the water emanating from the gypsiferous sequence which contains a high sulphate content as evidenced at Burton on Trent where the water is said to be "Burtonised" and used for brewing beer (Cooper et al. 2011). Evidence of gypsum dissolution is also given by sporadic records of subsidence and problems such as those encountered during the construction of the Derby Southern Bypass (Cooper and Saunders 2002) and A453 improvements west of Nottingham. The dissolution of the Triassic gypsum can lead to upstanding outliers of partially dissolved rock, zones of complete dissolution and collapse or deeper zones of partial dissolution (see section on construction). Similar features are described in the former Chellaston quarries and gypsum of the Dove valley; here cylindrical cavities (wash holes or water washes) up to nearly $5 \mathrm{~m}$ across and commonly connecting to the surface have also been recorded (Cooper 1996; Sherlock and Hollingworth 1938; Smith 1918; Wynne 1906; Young 1990). In a few places, such as East Leake and Keyworth to the south of Nottingham subsidence has been attributed to gypsum dissolution and ingress of surface water washing material into the cavities caused by the dissolution (T Colman pers. comm. 2012).

\section{Ground investigation: surveying, geophysics and boreholes in gypsum areas}

Following on from a literature review, the starting point for ground investigation is geomorphological and geological surveying that is required to identify the subsidence features that constitute the basis for making sinkhole susceptibility and hazard maps. Field surveying is indispensable and verbal information from farmers, residents and local government officials can add considerably to the data on subsidence features. Multiple tools can be used to produce the best possible cartographic sinkhole inventory. Historical maps and multiple temporally-spaced sets of monoscopic or stereoscopic aerial photographs are essential starting points for a survey. These can be complemented by multispectral scanning (Cooper 1989) and geodetic techniques like LiDAR (Light Detection and Ranging) surveys or radar interferometry from aircraft or satellite (DinSar) (Castañeda et al. 2009). A complete karst inventory including subsidence features gives an indication of the spatial distribution and severity of the problem (Cooper 1986, 1998; Galve et al. 2009a) This type of information can then be analyzed with respect to other parameters using GIS techniques to produce susceptibility and hazard models (Cooper 2008b; Farrant and Cooper 2008; Galve et al. 2008; Galve et al. 2009b). 
The depth of the gypsum sequences over many of the areas in question, and the evolving nature of the subsidence phenomenon makes site investigation and remediation difficult. Generally, only shallow site investigations have been undertaken over the gypsum subsidence belt. Detailed investigations, for modern developments, are now demanded by the planning authorities (Thompson et al. 1996). If sites are investigated by boreholes alone, the size and spacing of the subsidence features would demand closely spaced boreholes (at around $10 \mathrm{~m}$ intervals or less) drilled to the base of the gypsum; commonly this is 40-60 m deep under the city of Ripon. However, because of the rapid dissolution of gypsum and likelihood of artesian water, any borehole drilled through the sequence has the potential to become a hydraulic pathway. This could encourage enhanced dissolution and possibly become a focus for future subsidence. Consequently, the number of boreholes should be kept to a minimum. Great care should be taken to ensure that they are properly grouted with sulphate-proof grout and that the integrity of the ground around them is not compromised.

Another potential problem with site investigation by drilling is the likelihood of triggering a subsidence event in already unstable ground. This could be caused by vibration or circulation of pressurised drilling fluids. These problems should be considered when planning site investigations in the context of the safety of the drill crew, the safety of people in nearby buildings and the associated insurance cover. Where such conditions are suspected it is prudent both to avoid disturbing the ground and to avoid development.

Site investigation should include cored boreholes through the strata, which should be logged by a competent geologist. The geologist should be able to identify gypsum in all its forms, and recognise dissolution and collapse features. In much of the archival site investigation data for Ripon, gypsum (except for satin spar) is commonly miss-identified as limestone. The most abundant form of gypsum encountered at and near outcrop here is grey alabastrine gypsum or alabaster. This gypsum is commonly mis-identified as grey limestone in boreholes. This mistake that can potentially lead to disastrous engineering problems with sites underlain by gypsum being designated as having competent limestone present beneath them (Cooper and Calow 1998). In general, the gypsum in Yorkshire and Durham is a pale grey compact alabaster with fibrous gypsum veins, whereas the underlying Cadeby Formation (of Yorkshire) or Ford Formation (of Teesside/Durham) are dolomitic limestone, which is pale yellowish brown and porous. This is not always the case and particular care is required in areas where the limestone beneath the gypsum has not been dolomitised. Other misleading situations include areas where the upper gypsum (Hayton Anhydrite equivalent) rests on the mainly grey limestones of the Brotherton formation (of Yorkshire) or Seaham Formation (of Teesside/ Durham). At the contact between the dolomite and the overlying gypsum, it is also fairly common for the underlying dolomite to be dedolomitised. When this happens, it is transformed into a poorly-cemented mesh of calcitic sand that breaks up easily and has a low bearing strength.

Drilling open holes and collecting chippings instead of coring can be cost effective. This method can be more reliable if automated or manual recording of the drill penetration rate is made (Cailleux and Toulemont 1983; Patterson et al. 1995). However, experience and skill is needed to interpret the drilling rate figures with the identification of the chippings material. Downhole geophysics, cross-hole geophysics 
and downhole optical and acoustic cameras can also help to understand the local karst geology (Yuhr et al. 2008).

A practical investigation technique is to use geophysics as part of a phased drilling and dynamic probing investigation. At Ripon, microgravity has successfully been used to delineate anomalies that have subsequently been drilled (Patterson et al. 1995). Computer-based modelling and field investigations show that microgravity can delineate breccia pipes and large cavities that breach, or come near to, the surface. However, even large caves, at depth, are difficult to image and edge effects of superficial deposits can partially conceal anomalies. Subsidence features have also been investigated using 2D and 3D resistivity tomography (Cooper 1998; Gutiérrez et al. 2009). This method has proved a faster survey method than microgravity and has shown many of the anomalies. The downside is that electrical methods are difficult to use in built up areas where pipes, cables and metal objects may be present.

In summary, areas underlain by gypsum can pose difficult problems for developers and engineers. Drilling on either a grid or on a random sample pattern both have little chance of finding all the anomalies on a site (Figure 7). Breccia pipes and near surface cavities can be present, and physical investigations of their locations, by all but the closest spaced borehole survey, is difficult. Geophysics can help to delineate anomalies, which can then be avoided or investigated as part of the site development (Thompson et al. 1996). Successful techniques include microgravity (Patterson et al. 1995) and various forms of resistivity and conductivity survey with 3D resistivity tomography being particularly effective (Cooper 2009; Kaufmann and Romanov 2009). Ground probing radar (GPR) has also been used in areas where the surface material is not clayey (Benito et al. 1995), but has not been used in Ripon. Geophysics combined with trenching has also proved effective in Spain (Gutiérrez et al. 2009). Detailed seismic reflection techniques have been used near Darlington and Ripon, but the method is very labour intensive and more expensive than the other methods including microgravity (Sargent and Goulty 2009, 2010). Geophysics is best used in conjunction with limited amounts of drilling; a phased approach of using geophysics to target "anomalies" and "normal" areas, followed by drilling has proved effective (Figure 7). 


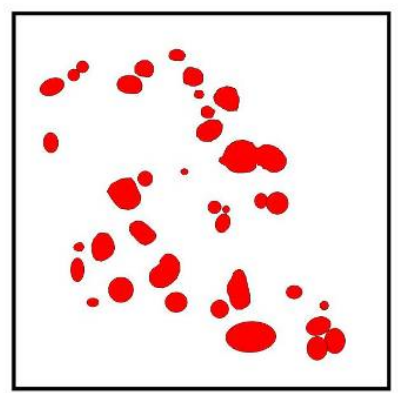

41 Subsidence features

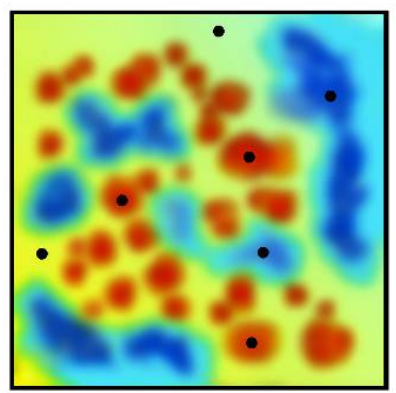

Geophysics followed by targetted boreholes to characterise the geology and subsidence

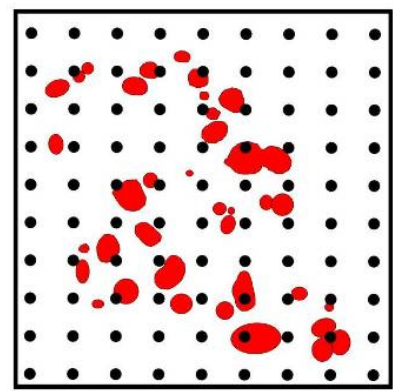

Grid of 90 boreholes found 5 subsidence features

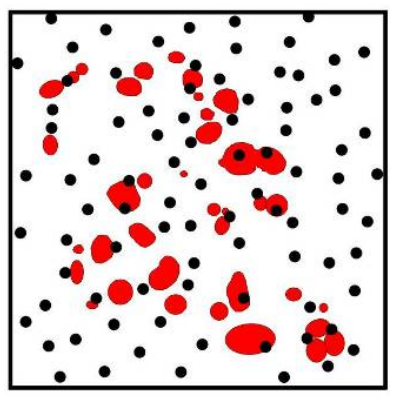

90 Random boreholes found 6 subsidence features

Figure 7. Actual subsidence features and the potential success of boreholes and geophysics for locating them.

\section{Gypsum dissolution as a hazard to civil engineering}

Subsidence caused by gypsum dissolution produces difficult conditions for building and construction; in many cases the collapses are so severe that little can be done to mitigate the problems. Consequently, good site investigation and hazard avoidance are the best approaches, followed by construction that can cope with any expected dissolution or subsidence. The interaction of gypsum and water in engineering projects can cause severe problems and catastrophic ground and structural failures. In the foundations of hydraulic structures, such as dams and canals, seepage through gypsum can lead to rapidly accelerating leakage, dissolution and failure. In the USA, the presence of gypsiferous beds beneath dam sites has resulted in at least 14 examples of dams losing water or failing (James 1992; Johnson 2008)), and at least two dams in China have also been affected (Lu and Cooper 1997). Leakage of canals and irrigation ditches along with irrigation and rainfall events are recorded as triggers for subsidence in the Zaragoza region of Spain (Galve et al. 2008; Gutiérrez et al. 2005). In the UK, at Ratcliffe south-west of Nottingham, power station foundations have been affected by water leakage and dissolution of thin Triassic gypsum beds (Seedhouse and Sanders 1993).

A phased approach to development is required with detailed site investigation and careful design. For housing construction in Ripon there is special planning control and 
buildings are now constructed on reinforced raft foundations (Thompson et al. 1996 and Figure 8); additional protection could be afforded by extending foundations with supporting beams outside the main footprint of the property (Cooper and Calow 1998). In subsidence-prone karstic areas it is important to use flexible service pipe materials and to guard against water loss and infiltration that itself could trigger subsidence. In some places, service trenches have been lined with waterproof membranes to stop this happening.

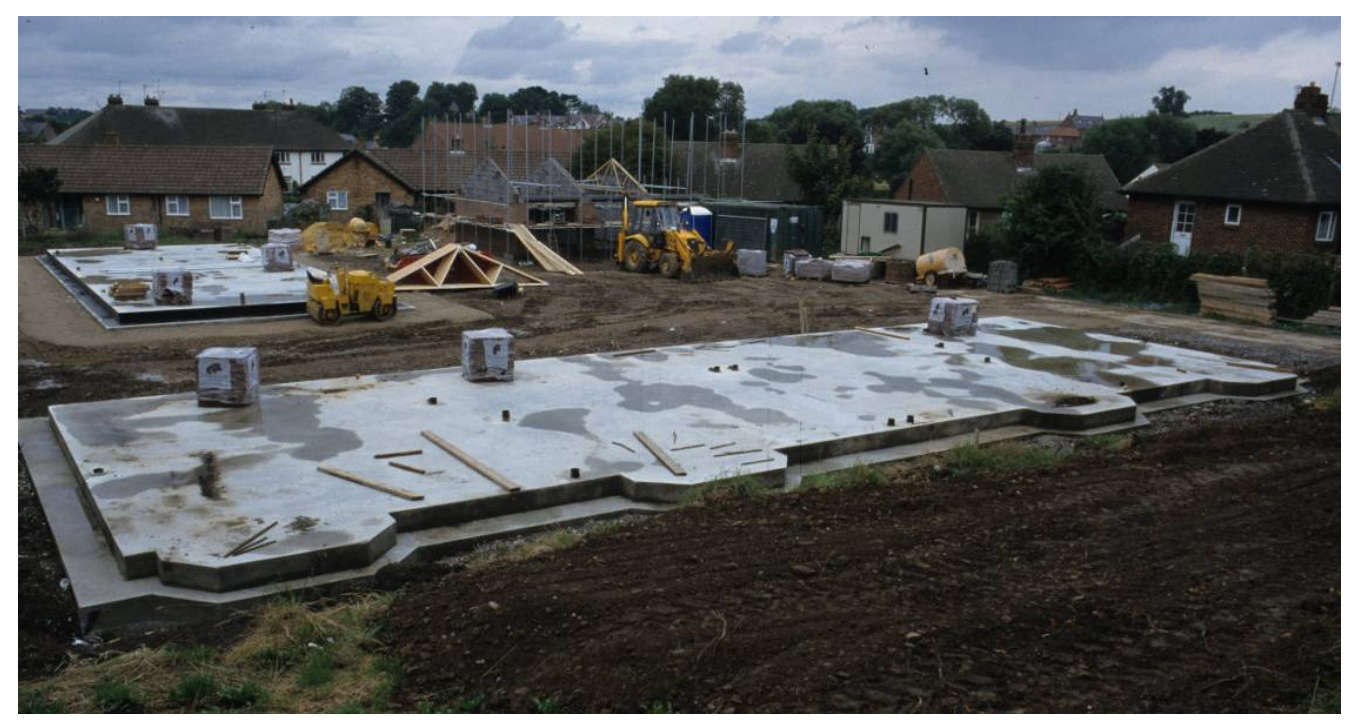

Figure 8. Massive rafted foundations at Ripon designed to cope with subsidence, note that the identified subsidence feature (just left of this picture) was avoided in this construction (Patterson et al, 1995; Photo A H Cooper $\odot$ NERC/BGS).

Linear structures such as roads and bridges are very prone to subsidence damage. At Ripon, the new Ure Bridge is built with redundant strength and the capability for the structure to loose any one of its pillar supports without collapse - Figure 9 and Figure 10 (Cooper and Saunders 2002). On the same stretch of road, the embankments are protected by two layers of strong geogrid material sandwiched in the embankment fill (Cooper and Saunders 2002; Jones and Cooper 2005; Thompson et al. 1996). This sandwich of material is designed to span cavities up to about $15 \mathrm{~m}$ across and sag rather than fail so that an indication of any problem becomes visible at the surface. Sensitive structures such as bridges and viaducts can be equipped with monitoring and warning systems such as those installed in the Paris road viaducts (Arnould 1970) and the bridge at Ripon (Cooper and Saunders 2002). 


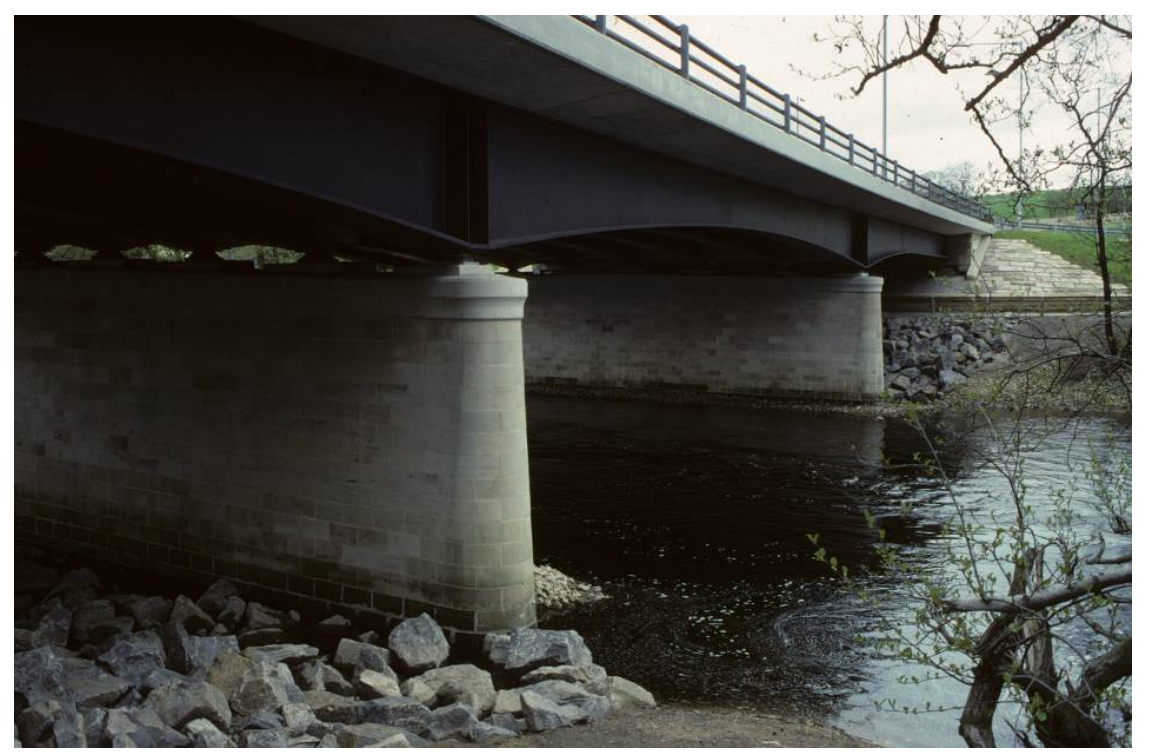

Figure 9. Ripon bypass bridge over the River Ure. The bridge span is one continuous structure designed not to collapse if subsidence removes the support of a pillar. Electronic monitoring is incorporated in the bridge bearings. (Photo A H Cooper (C) NERC/BGS).

Over gypsum dissolution in the Triassic strata, the Derby Southern Bypass used geophysics to locate cavities that were then filled. During construction large blocks of gypsum were excavated and removed while dissolved areas and old mine workings were grouted with sulphate-proof grout. Subsequently, the road was constructed of reinforced concrete to avoid any subsidence problems - Figure 11 (Cooper and Saunders 2002). Similar geophysical techniques and the removal of the gypsum have recently been undertaken for the improvement constructions on the A453 near Ratcliffe Power Station in Nottinghamshire (authors observations 2013). 


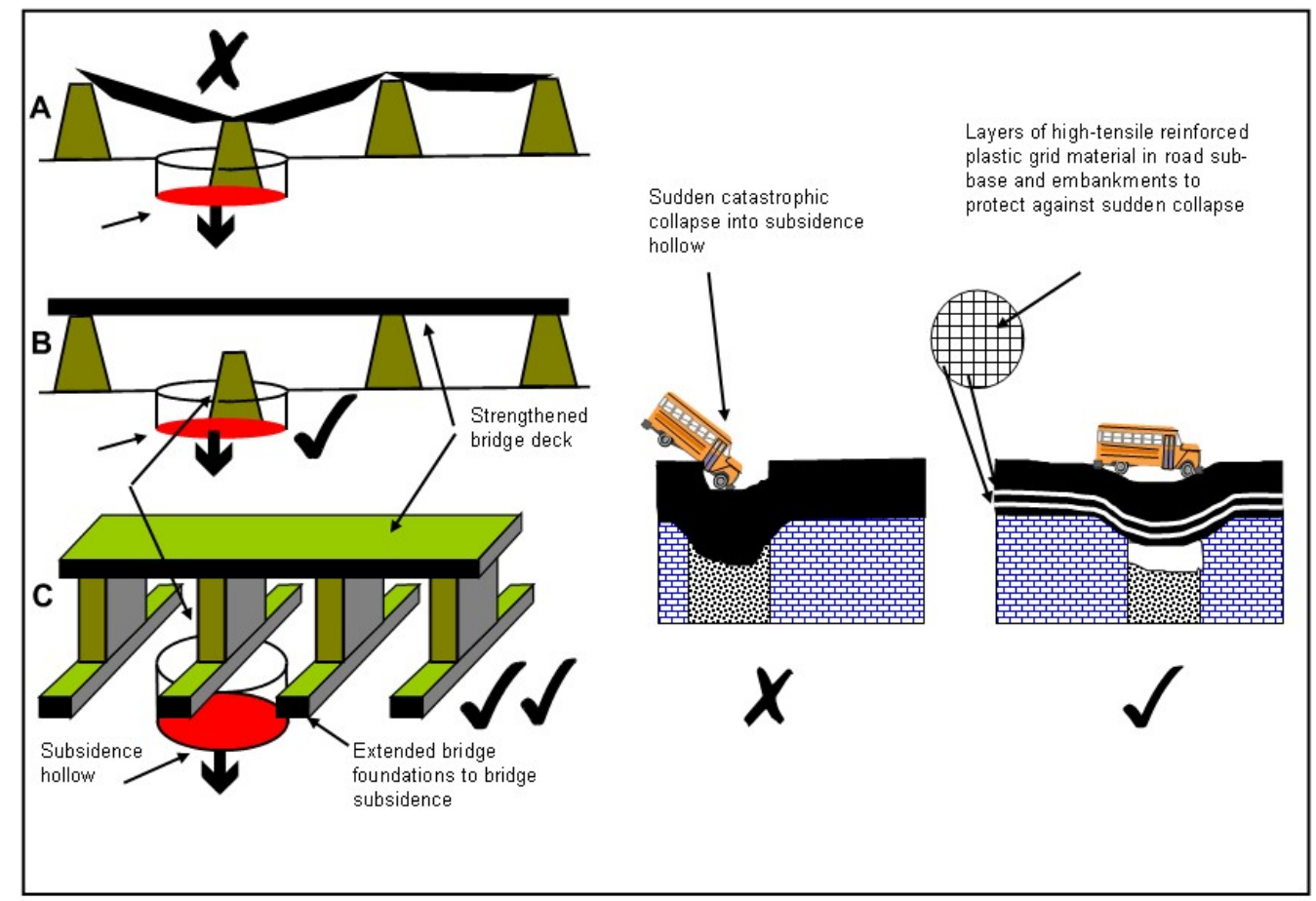

Figure 10. Reinforced bridge and road at Ripon designed to cope with subsidence problems (Cooper and Saunders, 2002; Jones and Cooper, 2005; Thompson et al. 1996).

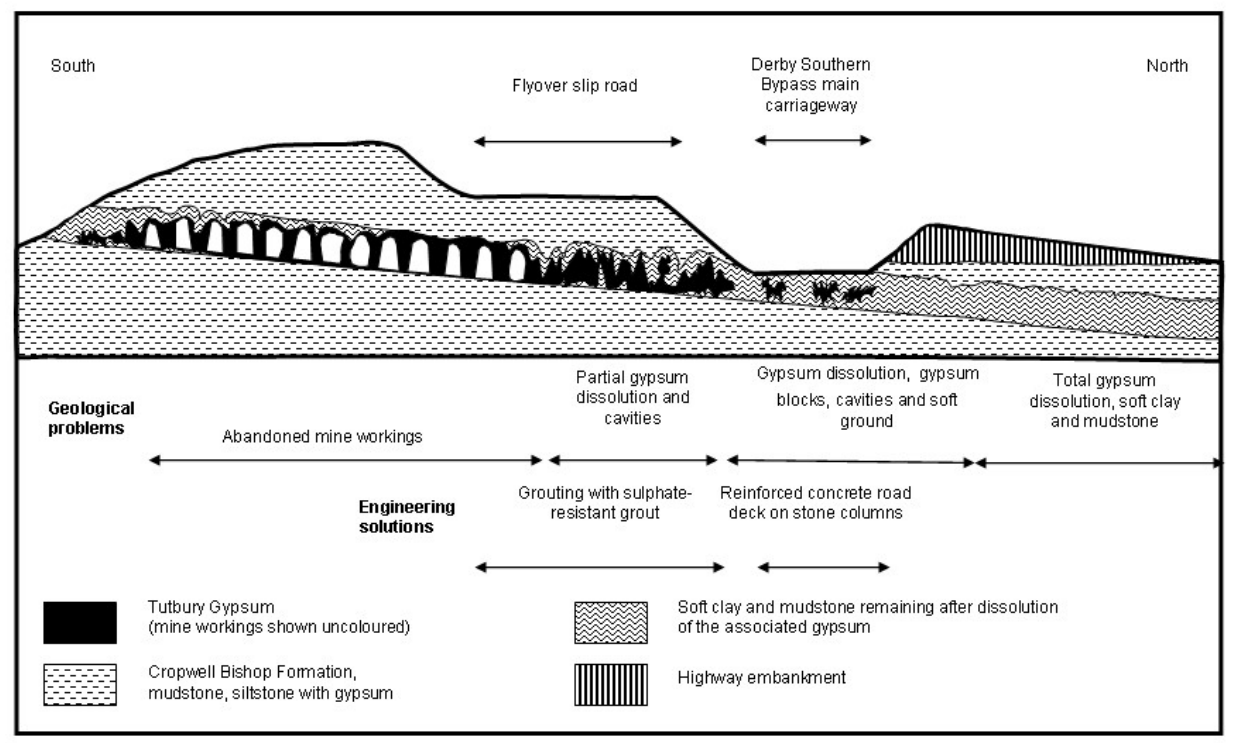

Figure 11. Section through the Tutbury Gypsum and associated strata on the Derby Southern Bypass (Cooper and Saunders, 2002)

Construction of infrastructure such as high-speed railway lines across gypsum karst areas need to consider the likelihood and sizes of potential collapses. Such studies 
have been carried out in Southern Germany (Molek 2003) and Spain (Guerrero et al. 2008) and may be required for parts of the proposed UK high speed rail network that crosses Permian and Triassic strata. The construction of high pressure gas pipelines also needs to consider these problems with appropriate investigation and design (Gibson et al. 2005)

Engineers have suggested that grouting can be used to stabilise gypsum caves; this technique has been used in the Palaeogene gypsum of the Paris area (Toulemont 1984), but the long-term outcome of the work is not reported. In general, grouting of a gypsum cave system is not advisable and for caves of the size found under places such as Ripon it would be completely impractical (Figure 12). Unless the caves are small, proved to be abandoned and completely dry, filling them with grout could alter the groundwater regime. This could cause dissolution in the adjacent ground in the same way that natural collapse may block a cave system, and through diversion of water channels, cause dissolution nearby. There could also be problems caused by locally raising the local water table which could trigger off subsidence. If a dry abandoned cave system was to be grouted, sulphate-resistant cement would have to be used. Similarly, for any site investigation boreholes it is essential to grout them completely with sulphate proof grout.

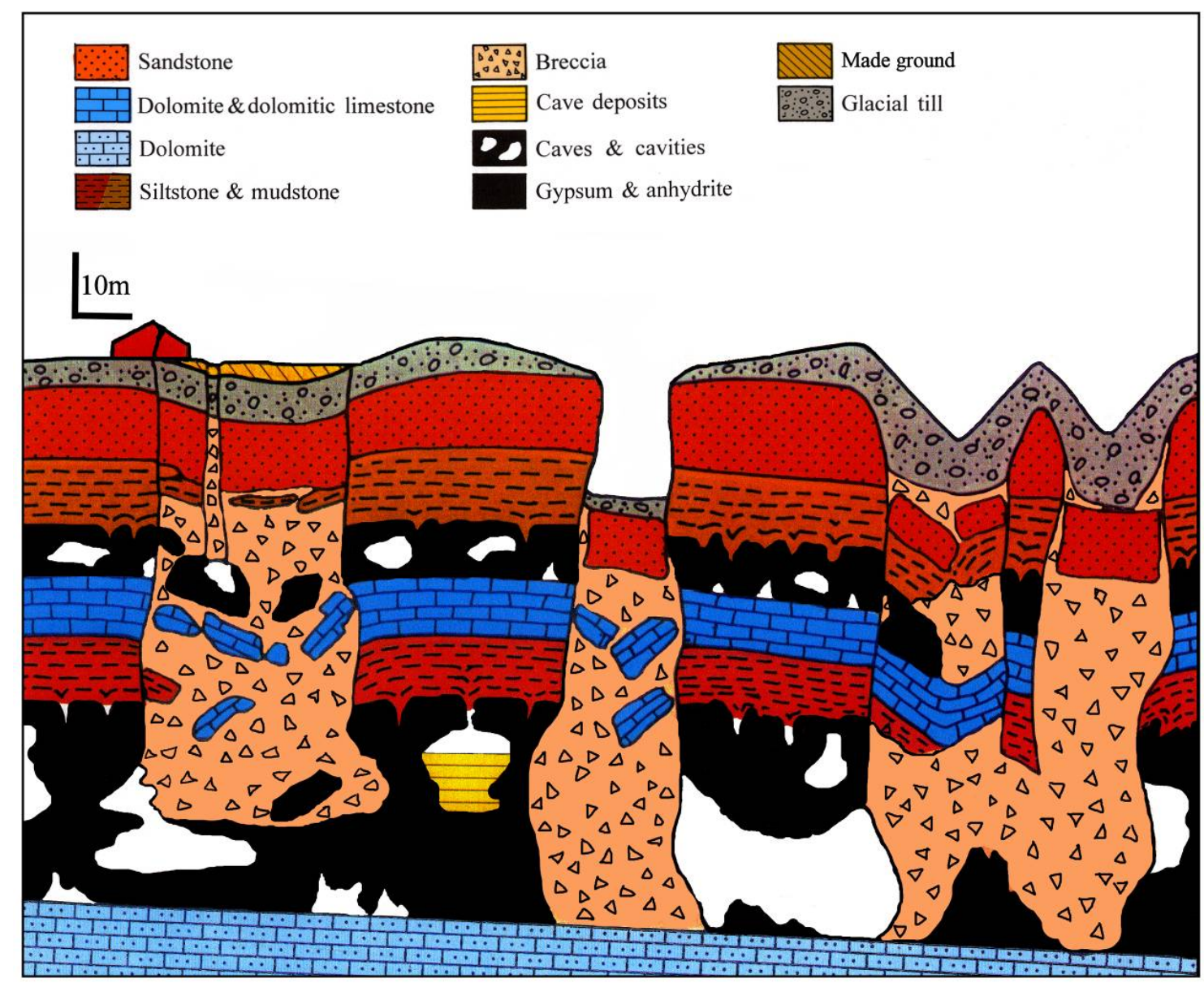

Figure 12. Stylised cross-section through gypsum dissolution subsidence features in the east of the Ripon subsidence belt.

With respect to foundations, conventional piled foundations, as already practised in Ripon and elsewhere, are also problematical. Piles through disturbed and unconsolidated 
deposits may achieve the required bearing strength on the base of the pile in either the superficial deposits or the bedrock below. However, since the bedrock contains gypsum beds, caverns might be present and these may propagate upwards thereby destabilising the piled structures. In some areas, it might be feasible to pile through the gypsum sequences, using bored piles. This has been suggested for Ripon with piles to the carbonate formation below, if the latter is not dedolomitised, but this could involve piling to depths of about $80 \mathrm{~m}$ to the east of the city. The use of sulphate-resistant cement would add to the cost and there is a danger that dissolution and collapse of the strata could place additional loads on the piles. This would necessitate the use of piles with a negative skin friction. Because of the prohibitive costs and likely difficulties associated with piling it is largely impractical except in the west of the subsidence belt where only a small amount of gypsum is present.

An alternative approach used has been to delineate and avoid any subsidence hollows and breccia pipes (Patterson et al. 1995). The constructions have then been placed within the site over the best ground conditions and designed to have minimal impact on the subsurface. They have also been designed to span any subsidence features that may potentially develop. This sort of approach requires extensive site investigation by engineering geologists working in close liaison with foundation engineers (Thompson et al. 1996).

\section{Problems related to water abstraction and injection in gypsum areas}

Gypsum aquifers, despite their hard sulphate-rich water, are commonly used for water supplies. In some places the availability of the hard sulphate-rich water is considered a benefit, as it is already "Burtonised" and suitable for use in beer brewing; along with the hops it gives the beer some of its bitter taste - hence the name of English beer "bitter". Several of the important brewing areas in the UK such as Burton on Trent and Tadcaster draw water from the gypsiferous sequences. Like all karst water systems gypsum karst can rapidly transmit pollutants (Lamont-Black et al. 2005). Gypsum karst aquifers are thus sensitive to both industrial and agricultural pollution and require careful exploitation and protection (Paukstys et al. 1999).

Water abstraction in gypsiferous terrains can aggravate the natural dissolution process by removing large volumes of sulphate-rich groundwater and drawing in aggressive recharge (Cooper 1988). Calculations for a major water abstractor pumping from the Permian gypsum and limestone beds of Northern England showed some alarming results. The water contained approximately $1200 \mathrm{ppm}$ of $\mathrm{SO}_{4}$ mainly as dissolved $\mathrm{CaSO}_{4}$ and the abstractor pumped $212 \mathrm{Ml}$ of water per annum. This was equivalent to removing approximately $200 \mathrm{~m}^{3}$ of gypsum a year from the area. It is likely that much of the dissolution represented the enlargement of joints over a wide area. However, adjacent to the boreholes where rapid water flow occurs, severe dissolution could occur and result in subsidence around the wellsite. In addition water pumping can also cause changes in the groundwater level triggering subsidence in the cover rocks and superficial deposits (Benito et al. 1995; Lamont-Black et al. 2002).

The development of Sustainable Drainage Systems (SUDS) is being promoted in England and Wales to help mitigate the effects of flooding caused by development, 
which is increasing the rapidity of surface runoff (Woods-Ballard et al. 2007). The Flood and Water Management Act 2010, for England and Wales, includes provision for the implementation of National Standards for SUDS (Department for Environment Food and Rural Affairs 2010). Identifying areas suitable for the safe installation of SUDS, in the light of legislation, will ensure that long-term performance is maintained while minimizing potential environmental impacts. In many areas SUDS can be effective and safe, with various solutions available including soak-aways, retention basins, porous pavements and surface materials. In most gypsum karst areas, the installation of infiltration based SUDS may be inappropriate. The disposal of surface water into the ground may cause pollution of groundwater or increase the susceptibility to geohazards. Water that infiltrates through the ground has the potential to wash fine materials out of the covering deposits and induce sinkhole development (Figure 13). This is a well-documented phenomenon alongside US highways where drainage ditches commonly cause the development of sinkholes adjacent to the road (Fleury 2009; Ford and Williams 2007; Waltham et al. 2005). Sinkholes have been reported alongside some modern British roads, especially where old land drains have been cut or new drainage channels installed. Sinkholes caused by leaking pipes are also well documented (McDowell 2005; Waltham et al. 2005).

Soak-aways from surface runoff or septic tanks are a well-known anthropogenic trigger that has caused subsidence in many places (Waltham et al. 2005). Within England and Wales there are policies for groundwater protection related to foul water soak-aways (Environment Agency 2010; Environment Alliance 2006) and information about infiltration testing and system design (British Standards Institution 2005, 2007). Septic tanks are not allowed in Zone 1 groundwater protection areas (which are the areas most susceptible to groundwater pollution), but the only apparent constraints are pollution prevention and suitable ground permeability assessed by percolation testing (Office of the Deputy Prime Minister 2002). No mention is made of potential karstic ground instability problems that can result from changes in the local input of water into the ground; these need to be considered in gypsum karst areas.

Ground source heat pumps and ground cooling systems (Arthur et al. 2010; Busby et al. 2009) are becoming popular as a source of green energy or an energy efficient cooling system. However, they could be problematical. Open loop installations must be avoided in gypsum and anhydrite not only because of the dissolution problems, but also because of the potential to hydrate anhydrite to gypsum (see section "The gypsum-anhydrite transition, expansion and heave"). This has happened in Staufen, Germany where a well-meaning "green" heat pump installation has caused severe heave to the recently restored town hall and 131 houses causing in excess of 40 million euros of damage (Goldscheider and Bechtel 2011; Staufen City Administration 2012). In addition to the dissolution and heave problems, the changes in groundwater levels associated with extraction and injection of water in open loop systems also has a potential to cause reactivation of breccia pipe features and subsidence/sinkholes due to the suffusion of overlying materials (Figure 14). 


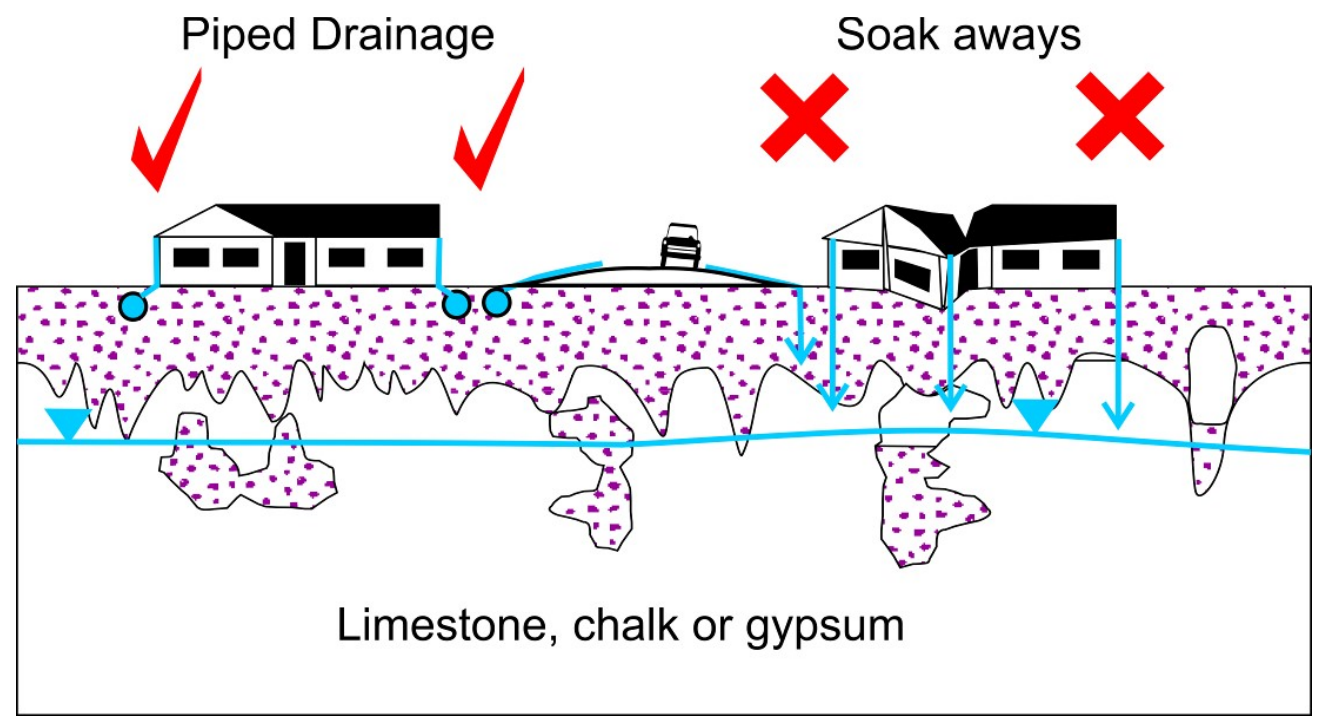

Figure 13. Subsidence problems caused by soak aways and their avoidance by correct drainage.

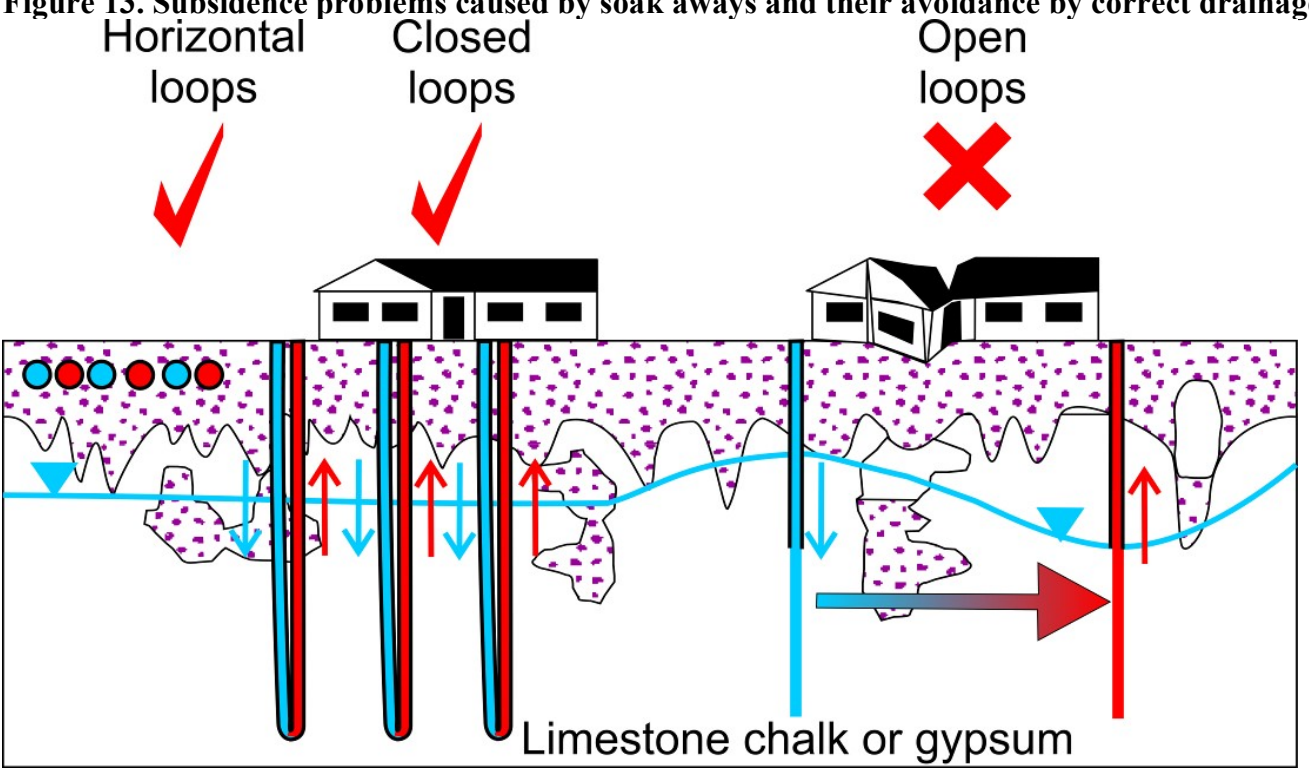

Figure 14. Subsidence caused by open loop ground source heat pump installations and their avoidance by using closed loop systems.

\section{Planning for subsidence}

The timing and precise location of the sudden, and sometimes catastrophic, subsidence caused by gypsum dissolution cannot yet be predicted. However, within England the gypsum subsidence belts have been defined and many of their controlling mechanisms described. Some areas are more at risk than others and deep buried valleys cutting through the gypsiferous beds are major controlling factors at Ripon, south of Darlington and Brotherton. Collapsed areas and existing breccia pipes remain 
potentially unstable and are best avoided for development (Cooper 2008b; Thompson et al. 1996). Areas adjacent to collapses are also suspect because of dissolution around the bases of the collapse pipes (Cooper 1986).

The dates and locations recorded for the historically recent subsidence events suggest concentration of water flow in the cave systems along certain specific paths (Figure 7 and (Cooper 1986, 1989, 1998)). The close grouping of subsidence hollows suggests that once a collapse has occurred the cave partially chokes and the dissolution continues in the adjacent strata. This commonly produces linear belts of subsidence related to the joint pattern. It also means that localities adjacent to, or in line with, existing subsidence hollows are probably more at risk from future subsidence. From the distribution of the subsidence features and their sizes, the worst areas can be avoided and development in the less susceptible areas tailored to cope with the magnitude of the likely subsidence events.

In Ripon there is a formal planning policy with check-lists and signed documents to help control and protect development in the area (Thompson et al. 1996; Thompson et al. 1998). To support this process the Ripon area has been divided into three development control zones: (A) no know gypsum present; (B) some gypsum present at depth; (C) gypsum present and susceptible to dissolution.

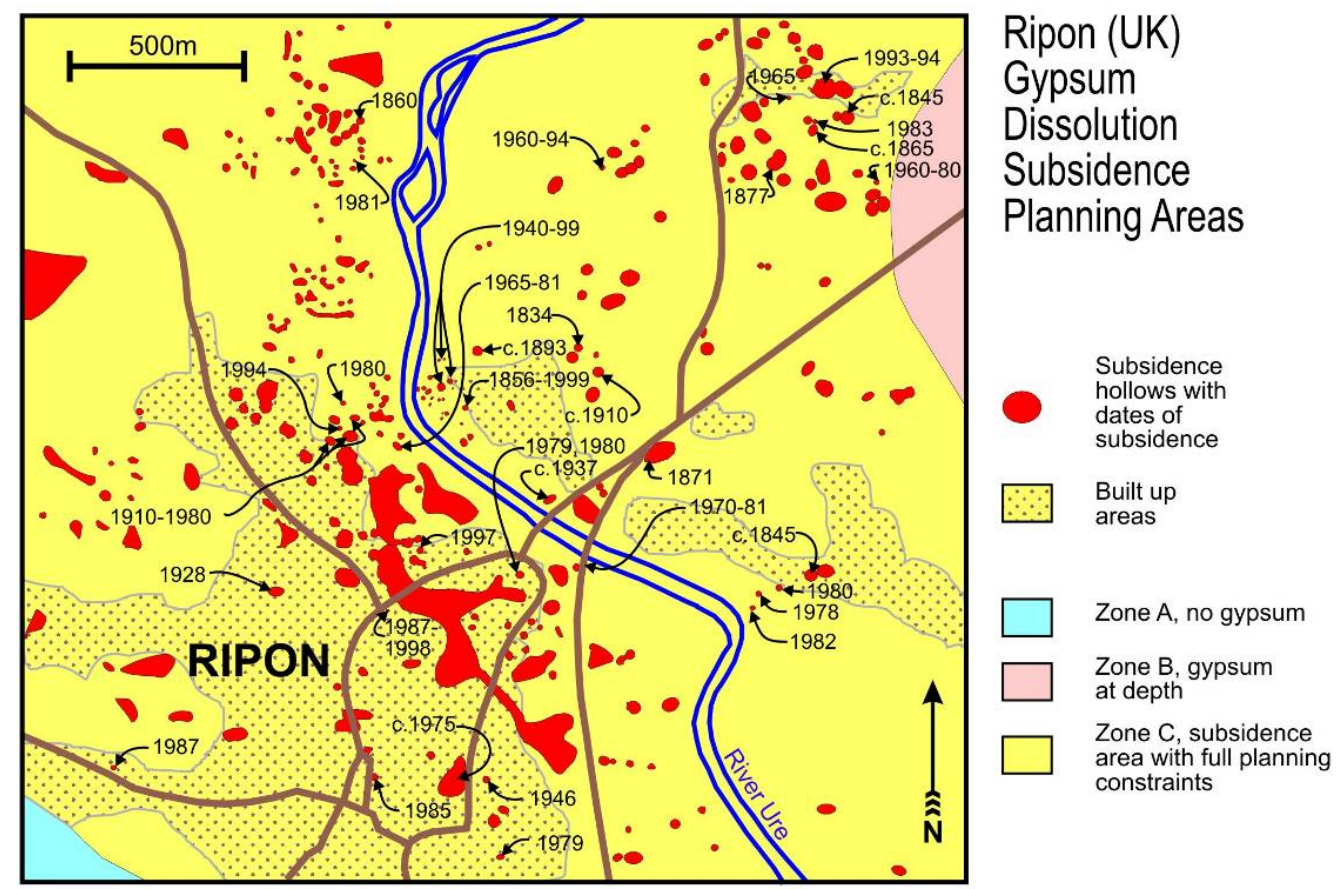

Figure 15. The planning zones and distribution of subsidence hollows in the Ripon area with the dates of collapse where they are known.

Within zone A no special planning constraints are imposed. In zone $\mathrm{B}$, where the risk of subsidence is small, a ground stability report prepared by a competent person is usually required and the problem is considered in local planning. 
The zone $\mathrm{C}$ area (which is most of Figure 15 except the very south-west and north east areas) is subject to significant formal constraints and controls on development, which local planning has to take into account. In this zone, a ground stability report prepared by a competent professional person is normally required before planning applications for new buildings, or change of use of buildings, are determined. In most cases this report has to be based on a geotechnical desk study and a site appraisal, followed by a programme of ground investigation designed to provide information needed for detailed foundation design (unless this information, such as boreholes, exists from a previous study). Where planning consent is given it may be conditional on the implementation of approved foundation or other mitigation measures, designed to minimise the impact of any future subsidence activity. One key to the implementation of this approach is the use of a proforma checklist to be completed and signed by a competent professional person. For the UK a competent person is defined in the report as Geotechnical Specialist who is "A Chartered Engineer or Chartered Geologist, with a postgraduate qualification in geotechnical engineering or engineering geology, equivalent at least to an MSc, and with three years of post-Charter practice in geotechnics; or a Chartered Engineer or Chartered Geologist with five years of post-Charter practice in geotechnics". In addition to these qualifications it is also desirable that the practitioner has experience of the problems though this is not formally stated. This procedure has been adopted by Harrogate Borough Council, but is likely to be subject to changes based on experience of its use. The procedure removes the responsibility from the planners to the developers. However some sites, where stability should have been more thoroughly investigated and assessed, have been developed and some modern houses have suffered subsidence. If the procedures were working correctly this should not have happened. Questions have been raised about the standards of investigations and the willingness of practitioners to sign off sites; a review of the procedures is required.

\section{Acknowledgements.}

The author thanks the following for helpful discussion and for critically reviewing the manuscript at various stages of its production: Dr Vanessa Banks, Dr Helen Reeves, Dr Andy Farrant, Dr Dave Giles, Dr Alan Thompson. This article is published with permission of the Executive Director of the British Geological Survey (NERC). 


\section{References}

Akhurst, M.C., Chadwick, R.A., Holliday, D.W., McCormac, M., McMillan, A.A., Millward, D., Young, B., Ambrose, K., Auton, C.A., Barclay, W.J., Barnes, R.P., Beddoe-Stephens, B., Glover, B.W., Hawkins, M.P., James, J.W.C., Johnson, H., Jones, N.S., Kimbell, G.S., MacPherson, K.A.T., Merritt, J.W., Milodowski, A.E., Riley, N.J., Robins, N.S., Stone, P. \& Wingfield, R.T.R. 1997. Geology of the west Cumbria district. Memoir of the British Geological Survey, Sheets 28, 37 and 47 (England and Wales). British Geological Survey, Keyworth, Nottingham, 138.

Arnould, M. 1970. Problems associated with underground cavities in the Paris region. Geological and geographical problems of areas of high population density.

Proceedings of the symposium, Association of Engineering Geologist, Sacramento, California, 1-25.

Arthur, S., Streetley, H.R., Valley, S., Streetley, M.J. \& Herbert, A.W. 2010. Modelling large ground source cooling systems in the Chalk aquifer of central London. Quarterly Journal of Engineering Geology and Hydrogeology, 43, 289-306, doi: 10.1144/1470-9236/09-039.

Arthurton, R.S. \& Wadge, A.J. 1981. Geology of the country around Penrith. Memoir of the Geological Survey of Great Britain (Sheet 24). HMSO, London.

Benito, G., Péres del Campo, P., Gutiérrez-Elorza, M. \& Sancho, C. 1995. Natural and human-induced sinkholes in gypsum terrain and associated environmental problems in NE Spain. Environmental Geology, 25, 156-164.

Boidin, E., Homand, F., Thomas, F. \& Yvon, J. 2009. Anhydrite-gypsum transition in the argillites of flooded salt workings in eastern France. Environmental Geology, 58, 531-542, doi: 10.1007/s00254-008-1528-1.

British Standards Institution. 2005. BS EN 12566-3:2005+A1:2009, Small wastewater treatment systems for up to 50PT. Packaged and/or site assemble domestic wastewater treatment plants. The British Standards Institution, 48.

British Standards Institution. 2007. BS 6297:2007+A1:2008, Code of practice for the design and installation of drainage fields for use in wastewater treatment. 44.

Burgess, I.C. \& Holliday, D.W. 1979. Geology of the country around Brough-underStainmore. Memoirs of the Geological Survey of Great Britain (Sheet 31 including parts of sheets 25 and 30 (England and Wales)).

Busby, J., Lewis, M., Reeves, H. \& Lawley, R.S. 2009. Initial geological considerations before installing ground source heat pump systems. Quarterly Journal of Engineering Geology and Hydrogeology, 42, 295-306.

Cailleux, J.B. \& Toulemont, M. 1983. La reconnaissance des cavites souterraines par methods diagraphiques. Bulletin of the International Association of Engineering Geology, 26-27, 33-42. 
Castañeda, C., Gutiérrez, F., Manunta, M. \& Galve, J.P. 2009. DInSar measurements of ground deformation by sinkholes, mining subsidence, and landslides Ebro River, Spain. Earth Surface Processes and Landforms, 34, 1562-1574, doi:

10.1002/esp.1848.

Cooper, A.H. 1986. Foundered strata and subsidence resulting from the dissolution of Permian gypsum in the Ripon and Bedale areas, North Yorkshire. In: Harwood, G.M. \& Smith, D.B. (eds.) The English Zechstein and related topics, 127-139.

Cooper, A.H. 1988. Subsidence resulting from the dissolution of Permian gypsum in the Ripon area; its relevance to mining and water abstraction. In: Bell, F.G., Culshaw, M.G., Cripps, J.C. \& Lovell, M.A. (eds.) Engineering Geology of Underground Movements. Geological Society of London, Engineering Geology Special Publication No. 5, 387-390.

Cooper, A.H. 1989. Airborne multispectral scanning of subsidence caused by Permian gypsum dissolution at Ripon, North Yorkshire. Quarterly Journal of Engineering Geology, 22, 219-229.

Cooper, A.H. 1996. Gypsum: geology, quarrying, mining and geological hazards in the Chellaston area of South Derbyshire. British Geological Survey Technical Report WA/96/30.

Cooper, A.H. 1998. Subsidence hazards caused by the dissolution of Permian gypsum in England: geology, investigation and remediation. In: Maund, J.G. \& Eddleston, M. (eds.) Geohazards in Engineering Geology. Engineering Geology Special Publication 15. The Geological Society of London, 265-275.

Cooper, A.H. 2002. Environmental problems caused by gypsum karst and salt karst in Great Britain. Carbonates and Evaporites, 17, 116-120.

Cooper, A.H. 2007. Gypsum dissolution geohazards at Ripon, North Yorkshire, UK. Engineering Geology For Tomorrow's Cities. International Association for Engineering Geology, Nottingham.

Cooper, A.H. 2008a. The classification, recording, databasing and use of information about building damage caused by subsidence and landslides. Quarterly Journal of Engineering Geology and Hydrogeology, 41, 409-424.

Cooper, A.H. 2008b. The GIS approach to evaporite karst geohazards in Great Britain. Environmental Geology, 53, 981-992.

Cooper, A.H. 2009. Gypsum dissolution geohazards at Ripon, North Yorkshire, UK: CD IAEG2006 UK Field Trip 2. In: Culshaw, M.G., Reeves, H.J., Jefferson, I. \& Spink, T.W. (eds.) Engineering Geology for Tomorrow's Cities. Geological Society, London.

Cooper, A.H. \& Burgess, I.C. 1993. Geology of the country around Harrogate; Sheet 62 (England and Wales). British Geological Survey.

Cooper, A.H. \& Calow, R. 1998. Avoiding gypsum geohazards: guidance for planning and construction, British Geological Survey Technical Report, WC/98/5. 
Cooper, A.H., Farrant, A.R., Adlam, K.A.M. \& Walsby, J.C. 2001. The development of a national Geographic Information System (GIS) for British karst geohazards and risk assessment. In: Beck, B.F. \& Herring, J.G. (eds.) Geotechnical and Environmental Applications of Karst Geology and Hydrology: Proceedings of the eighth Multidisciplinary Conference on Sinkholes and the Engineering and Environmental Impacts of Karst, April 1-4th Louisville, Kentucky. Balkema, Rotterdam, 125-130.

Cooper, A.H., Farrant, A.R. \& Price, S.J. 2011. The use of karst geomorphology for planning, hazard avoidance and development in Great Britain. Geomorphology, 134, 118-131, doi: 10.1016/j.geomorph.2011.06.004.

Cooper, A.H., Odling, N.E., Murphy, P.J., Miller, C., Greenwood, C.J. \& Brown, D.S. 2013. The role of sulfate-rich springs and groundwater in the formation of sinkholes over gypsum in Eastern England. In: Land, L., Doctor, D.H. \& Stephenson, J.B. (eds.) Sinkholes and the Engineering and Environmental Imapacts of Karst: Proceedings of the Thirteeth Multidisciplinary Conference, May 6-10. . National Cave and Karst Research Institute, Carlsbad, New Mexico, 141-150.

Cooper, A.H. \& Saunders, J.M. 2002. Road and bridge construction across gypsum karst in England. Engineering Geology, 65, 217-223.

Crammond, N.J. 2003. The thaumasite form of sulfate attack in the UK. Cement and Concrete Composites, 25, 809-818, doi: 10.1016/S0958-9465(03)00106-9.

Czerewko, M.A., Cross, S.A., Dumelow, P.G. \& Saadvandi, A. 2011. Assessment of pyritic Lower Lias mudrocks for earthworks. Geotechnical Engineering, 162, 59-77, doi: 10.1680/geng.2011.164.2.59.

Department for Environment Food and Rural Affairs. 2010. Flood and Water Management Act. World Wide Web Address:

www.defra.gov.uk/environment/flooding/policy/fwmb.

Dunham, K.C. \& Hollingworth, S.E. 1947. Excursion to Penrith and north-west. Mineralogical Magazine, 28, 248-254.

Einstein, H.H. 1996. Tunnelling in difficult ground - swelling behaviour and identification of swelling rocks. Rock Mechanics and Rock Engineering, 29, 113-124.

Environment Agency. 2010. Groundwater protection: Policy and practice (GP3 - Part 4) http://publications.environment-agency.gov.uk/pdf/GEHO0708BOGU-e-e.pdf accessed 22nd March 2011.

Environment Alliance. 2006. Pollution prevention guidelines: Treatment and disposal of dewage where no foul sewer is available: PPG4. Environment Agency, 12.

Farrant, A.R. \& Cooper, A.H. 2008. Karst geohazards in the UK: the use of digital data for hazard management. Quarterly Journal of Engineering Geology and Hydrogeology, 41, 339-356.

Firman, R.J. 1964. Gypsum in Nottinghamshire. Bulletin of the Peak District Mines Historical Society, 4, 189-203. 
Firman, R.J. 1984. A geological approach to the history of English alabaster. Mercian Geologist, 9, 161-178.

Fleury, S. 2009. Land Use Policy and Practice on Karst Terrains - Living on Limestone. Springer.

Ford, D. \& Williams, P. 2007. Karst hydrogeology and geomorphology. John Wiley and Sons Ltd, Chichester, England.

Forster, A., Culshaw, M.G. \& Bell, F.G. 1995. Regional distribution of sulphate in rocks and soils of Britain. In: Eddleston, M., Walthall, S., Cripps, J.C. \& Culshaw, M.G. (eds.) Engineering Geology of Construction. Geological Society Engineering Geology Special Publication No 10, 95-104.

Galve, J.P., Gutiérrez, F., Lucha, P., Bonachea, J., Cendrero, A., Gimeno, M.J., Gutiérrez, M., Pardo, G., Remondo, J. \& Sánchez, J.A. 2009a. Sinkholes in the saltbearing evaporite karst of the Ebro River valley upstream of Zaragoza city (NE Spain). Geomorphological mapping and analysis as a basis for risk management. Geomorphology, 108, 145-158.

Galve, J.P., Gutiérrez, F., Lucha, P., Guerrero, J., Bonachea, J., Remondo, J. \& Cendrero, A. 2008. Probabilistic sinkhole modeling for hazard assessment. Earth Surface Processes and Landforms, 34, 437-452, doi: 10.1002/esp.1753.

Galve, J.P., Gutiérrez, F., Remondo, J., Bonachea, J., Lucha, P. \& Cendrero, A. 2009b. Evaluating and comparing methods of sinkhole susceptibility mapping in teh Ebro Valley evaporite karst (NE Spain). Geomorphology, 111, 160-172, doi: 10.1016/j-geomorph2009.04.017.

Gibson, A.D., Forster, A., Culshaw, M.G., Cooper, A.H., Farrant, A.R., Jackson, N. \& Willet, D. 2005. Rapid geohazard assessment system for the UK Natural Gas Pipeline Network. Geoline 2005 : International Symposium on Geology and Linear Developments, 23rd-25th May 2005, Lyon, France.

Goldscheider, N. \& Bechtel, T.D. 2011. Editors' message: The housing crisis from underground - damage to the historic town by geothermal drillings through anhydrite, Staufen, Germany. Hydrogeology Journal, 17, 491-493, doi: 10.1007/s10040-0090458-7.

Guerrero, J., Gutiérrez, F., Bonachea, J. \& Pedro, L. 2008. A sinkhole susceptibility zonation based on paleokarst analysis along a stretch of the Madrid-Barcelona highspeed railway built over gypsum- and salt-bearing evaporites (NE Spain). Engineering Geology, 102, doi: 10.1016.j.enggeo.2008.07.010.

Gutiérrez, F., Galve, J.P., Lucha, P., Bonachea, J., Jordá, L. \& Jordá, R. 2009. Investigation of a large collapse sinkhole affecting a multi-storey building by means of geophysics and the trenching technique (Zaragoza city, NE Spain). Environmental Geology, 58, 1107-1122, doi: 10.1007/s00254-008-1590-8.

Gutiérrez, F., Gutiérrez, M., Marin, C., Desir, G. \& Maldonado, C. 2005. Spatial distribution, morphometry and activitiy of La Puebla de Alfindén sinkhole field in the 
Ebro river valley (NE Spain): applied aspects for hazard zonation. Environmental Geology, 48, 360-369, doi: 10.1007/s00254-005-1280-8.

Gysel, M. 2002. Anhydrite Dissolution Phenomena: Three Case Histories of Anhydrite Karst Caused by Water Tunnel Operation. Rock Mechanics and Rock Engineering, 35, 1-21.

Hawkins, A.B. \& Pinches, G.M. 1987. Cause and significance of heave at Llandough Hospital, Cardiff - a case history of ground floor heave due to gypsum growth. Quarterly Journal of Engineering Geology, 20, 41-57.

Holliday, D.W. 1993. Geophysical log signatures in the Eden Shales (Permo-Triassic) of Cumbria and their regional significance Proceedings of the Yorkshire Geological Society, 49, 345-354.

Hughes, R.A. 2003. Permian and Triassic rocks of the Appleby district (part of Sheet 30, England and Wales). British Geological Survey, Research Report, RR/02/01, $21 \mathrm{pp}$.

Jago, G. 2013. Report of lecture: Gypsum Geohazards and Road Construction by A H Cooper, East Midlands Regional Group of the Geological Society, 18th November 2013. World Wide Web Address:

http://www.geolsoc.org.uk/ /media/shared/documents/specialist $\% 20$ and $\% 20$ regional \%20groups/EMRG/2013\%20Meeting\%20Report.ashx.

James, A.N. 1992. Soluble Materials in Civil Engineering. Ellis Horwood, Chichester.

James, A.N., Cooper, A.H. \& Holliday, D.W. 1981. Solution of the gypsum cliff (Permian Middle Marl) by the River Ure at Ripon Parks, North Yorkshire. Proceedings of the Yorkshire Geological Society, 43, 433-450.

Johnson, K.S. 2008. Gypsum-karst problems in constructing dams in the United States. Environmental Geology, 53, 945-950.

Jones, C.J.F.P. \& Cooper, A.H. 2005. Road construction over voids caused by active gypsum dissolution, with an example from Ripon, North Yorkshire, England. Environmental Geology, 48, 384-394, doi: 10.1007/s00254-005-1282-6.

Jowett, E.C., Cathles, L.M. \& Davis, B.W. 1995. Predicting depths of gypsum dehydration in evaporitic sedimentary basins. The American Association of Petroleum Geologists Bulletin, 77, 402-413.

Kaufmann, G. \& Romanov, D. 2009. Geophysical investigations of a sinkhole in the northern Harz foreland (North Germany). Environmental Geology, 58, 401-405, doi: $10.1007 / \mathrm{s} 00254-008-1598-0$.

Kendall, C.G. \& Alsharhan, A. 2011. Quaternary Carbonate and Evaporite Sedimentary Facies and Their Ancient Analogues: A Tribute to Douglas James Shearman: Vol 43. Special Publication Number 43 of the International Association of Sedimentologists. Blackwell, 496. 
Klimchouk, A. 1992. Large gypsum caves in the Western Ukraine and their genesis. Cave Science, 19, 3-11.

Klimchouk, A. 1996. The dissolution and conversion of gypsum and anhydrite. In: Klimchouk, A., Lowe, D, Cooper, A and Sauro, U (ed.) Gypsum karst of the world. International Journal of Speleology Vol. 25, 9-20.

Klimchouk, A. 2000. Dissolution and conversions of gypsum and anhydrite. In: Klimchouk, A., Ford, D.C., Palmer, A.N. \& Dreybrodt, W. (eds.) Speleogenesis: Evolution of Karst Aquifers. National Speleological Society, 160-168.

Klimchouk, A. \& Andrejchouk, V. 2005. Karst breakdown mechanisms from observations in the gypsum caves of the Western Ukraine: implications for subsidence hazard assessment. Environmental Geology, 48, 336-359.

Klimchouk, A. \& Andrejchuk, V. 1996. Sulphate rocks as an arena for karst development. In: Klimchouk, A., Lowe, D., Cooper, A. \& Sauro, U. (eds.) Gypsum karst of the world. International Journal of Speleology Vol. 25, 9-20.

Klimchouk, A., Cucchi, F., Calaforra, J.M., Aksem, S., Finocchiaro, F. \& Forti, P. 1996a. The dissolution of gypsum from field observations. In: Klimchouk, A., Lowe, D., Cooper, A. \& Sauro, U. (eds.) Gypsum karst of the world. International Journal of Speleology Vol.25, 37-48.

Klimchouk, A., Lowe, D., Cooper, A. \& Sauro, U. 1996b. Gypsum karst of the world. International Journal of Speleology, 307pp.

Lamont-Black, J., Baker, A., Younger, P.L. \& Cooper, A.H. 2005. Utilising seasonal variations in hydrogeochemistry and excitation-emission fluorescence to develop a conceptual groundwater flow model with implications for subsidence hazards: an example from Co. Durham, UK. Environmental Geology, 48, 320-335, doi: $10.1007 / \mathrm{s} 00254-005-1278-2$.

Lamont-Black, J., Younger, P.L., Forth, R.A., Cooper, A.H. \& Bonniface, J.P. 1999. Hydrogeological monitoring strategies for investigating subsidence problems potentially attributable to gypsum karstification. Hydrogeology and Engineering Geology of Sinkholes and Karst - 1999, 141-148.

Lamont-Black, J., Younger, P.L., Forth, R.A., Cooper, A.H. \& Bonniface, J.P. 2002. A decision-logic framework for investigating subsidence problems potentially attributable to gypsum karstification. Engineering Geology, 65, 205-215.

Longstaffe, W.H.D. 1854. The History and Antiquities of the Parish of Darlington. The proprietors of the Darlington and Stockton Times, London: republished by Patric and Shotton.

Longworth, I. 2004. Assessment of sulfate-bearing ground for soil stabilisation for built development. World Wide Web Address: http://www.nce.co.uk/assessment-ofsulfate-bearing-ground-for-soil-stabilisation-for-built-development/744870.article.

Lu, Y.R. \& Cooper, A.H. 1997. Gypsum karst geohazards in China. Engineering Geology and Hydrogeology of Karst Terranes, 117-126. 
McDowell, P.W. 2005. Geophysical investigations of sinkholes in chalk, U.K. Case Study No 9. In: Waltham, A.C., Bell, F.G. \& Culshaw, M.G. (eds.) Sinkholes and Subsidence. Karst and Cavernous Rocks in Engineering and Construction. Praxis, Chichester, 313-316.

Mc Nerney, P. 2000. The extent of subsidence caused by the dissolution of gypsum in Ripon, North Yorkshire. BSc thesis, Sunderland University.

Meyer, H.O.A. 1965. Revision of the stratigraphy of the Permian evaporites and associated strata in north-western England. Proceedings of the Yorkshire Geological Society, 35, 71-89.

Molek, H. 2003. Engineering-geological and geomechanical analysis for the fracture origin of sinkholes in the realm of a high velocity railway line. In: Beck, B.F. (ed.) Sinkholes and the engineering and environmental impacts of karst: proceedings of the ninth multidisciplinary conference, September 6-10, 2003. American Society of Civil Engineers, Huntsville, Alabama, 551-558.

Mossop, G.D. \& Shearman, D.J. 1973. Origins of secondary gypsum rocks. Transactions of the Institution of Mining and Metallugy (section B Applied Earth Sciences), 82, B147-154.

Mottahed, P. \& Szeki, A. 1982. The collapse of room and pillar working in a shaley gypsum mine due to dynamic loading. Strata Mechanics: Developments in Geotechnical Engineering Elsevier, 260-264.

Office of the Deputy Prime Minister. 2002. The Building Regulations 2000; section $\mathrm{H}$ : Drainage and waste disposal http://www.planningportal.gov.uk/uploads/br/BR_PDF_ADH_2002.pdf accessed 22nd March 2011.

Patterson, D.A., Davey, J.C., Cooper, A.H. \& Ferris, J.K. 1995. The investigation of dissolution subsidence incorporating microgravity geophysics at Ripon, Yorkshire. Quarterly Journal of Engineering Geology, 28, 83-94.

Paukstys, B., Cooper, A.H. \& Arustiene, J. 1999. Planning for gypsum geohazards in Lithuania and England. Engineering Geology, 52, 93-103.

Powell, J.H., Cooper, A.H. \& Benfield, A.C. 1992. Geology of the country around Thirsk; Sheet 52 (England and Wales). British Geological Survey.

Rogers, C. 1994. To be a gypsum miner. Pentland Press, Bishop Auckland, Durham.

Ryder, P.F. \& Cooper, A.H. 1993. A cave system in Permian gypsum at Houtsay Quarry, Newbiggin, Cumbria, England. Cave Science, 20, 23-28.

Sargent, C. \& Goulty, N.R. 2009. Seismic reflection survey for investigation of gypsum dissolution and subsidence at Hell Kettles, Darlington, UK. Quarterly Journal of Engineering Geology and Hydrogeology, 42, 31-38, doi: 10.1144/1470-9236/07071 . 
Sargent, C. \& Goulty, N.R. 2010. Shallow seismic reflection profiles over Permian strata affected by gypsum dissolution in NE England. Quarterly Journal of Engineering Geology and Hydrogeology, 43, 221-232, doi: DOI 10.1144/14709236/08-115.

Seedhouse, R.L. \& Sanders, R.L. 1993. Investigations for cooling tower foundations in Mercia Mudstone at Ratcliffe-on-Soar, Nottinghamshire. In: Cripps, J.C., Coulthard, J.C., Culshaw, M.G., Forster, A., Hencher, S.R. \& Moon, C. (eds.) The Engineering Geology of Weak Rock. Proceedings of the 26th annual conference of the Engineering Group of the Geological Society. Leeds, September 1990. A A Balkema, Rottedam.

Sherlock, R.L. \& Hollingworth, S.E. 1938. Gypsum and anhydrite \& celestine and strontianite. His Majesty's Stationery Office, London.

Smith, B. 1918. The chellaston gypsum breccia and its relation to the gypsumanhydrite deposits of Britain. Quarterly Journal of the Geological Society, London, 77.

Staufen City Administration. 2012. News - The ground is rising in Staufen. World Wide Web Address: http://www.staufen.de/en/news/.

Thompson, A., Hine, P.D., Greig, J.R. \& Peach, D.W. 1996. Assessment of subsidence arising from gypsum dissolution with particular reference to Ripon. Symonds Travers Morgan, East Grinstead (288pp).

Thompson, A., Hine, P.D., Peach, D.W., Frost, L. \& Brook, D. 1998. Subsidence Hazard Assessment as a basis for Planning Guidance in Ripon. In: Maund, J.G. \& Eddleston, M. (eds.) Geohazards in Engineering Geology. , Engineering Geology Special Publication 15. The Geological Society of London, 415-426.

Toulemont, M. 1984. Le karst gypseux du Lutétien supérieur de la région parisienne. Charactéristiques et impacts sur le milieu urbain. Revue de Géologie Dynamique et de Géographie Physique, 25, 213-228.

Tyler, I. 2000. Gypsum in Cumbria. Blue Rock Publications.

Waltham, A.C., Bell, F.G. \& Culshaw, M.G. 2005. Sinkholes and Subsidence; Karst and cavernous rocks in engineering and construction. Praxis, Springer, Chichester, UK.

Waltham, A.C. \& Cooper, A.H. 1998. Features of gypsum caves and karst at Pinega (Russia) and Ripon (England). Cave and Karst Science, 25, 131-140.

Woods-Ballard, B., Kellagher, R., Martin, P., Jeffries, C., Bray, R. \& Shaffer, P. 2007. The SUDS Manual. CIRIA, London.

Worley, N. \& Reeves, H. 2007. Field guide: application of engineering geology to surface mine design, British Gypsum, Newark, Nottinghamshire: Sunday 1st April 2007 available from http://nora.nerc.ac.uk/3225/. Yorkshire Geological Society. 
Wynne, T.T. 1906. Gypsum and its occurrence in the Dove Valley. Transactions of the Institute of Mining Engineers, 32, 171-192.

Young, J. 1990. Alabaster. Derbyshire Museums Service.

Yuhr, L.B., Kaufmann, R., Casto, D., Singer, M., McElroy, B. \& Glasgow, J. 2008. Karst characterization of the Marshall Space Flight Center: Two years after. In: Yuhr, L.B., Alexander, E.C. \& Beck, B.F. (eds.) Sinkholes and the Engineering and

Environmental Impacts of Karst. ASCE Geotechnical Special Publication, 98-109. 